\title{
On the Horizon: Targeting Next- Generation Immune Checkpoints for Cancer Treatment
}

\author{
Grazia R. Tundo ${ }^{\mathrm{a}}$ Diego Sbardella ${ }^{\mathrm{a}}$ Pedro M. Lacal ${ }^{\mathrm{b}}$ Grazia Graziani $^{\mathrm{c}}$ \\ Stefano Marini ${ }^{\text {b }}$ \\ ${ }^{a}$ Department of Clinical Sciences and Translational Medicine, University of Rome Tor Vergata, Rome, Italy; \\ b Laboratory of Molecular Oncology, Istituto Dermopatico dell'Immacolata, IDI-IRCCS, Rome, Italy; ' Department of \\ Systems Medicine, University of Rome Tor Vergata, Rome, Italy
}

\section{Keywords}

Metastatic melanoma · Non-small cell lung cancer .

Nivolumab · Pembrolizumab · Atezolizumab

\begin{abstract}
Background: Immune checkpoints are critical regulatory pathways of the immune system which finely tune the response to biological threats. Among them, the CD-28/CTLA4 and PD-1/PD-L1 axes play a key role in tumour immune escape and are well-established targets of cancer immunotherapy. Summary: The clinical experience accumulated to date provides unequivocal evidence that anti-CTLA-4, PD-1, or PD-L1 monoclonal antibodies, used as monotherapy or in combination regimes, are effective in a variety of advanced/ metastatic types of cancer, with improved clinical outcomes compared to conventional chemotherapy. However, the therapeutic success is currently restricted to a limited subset of patients and reliable predictive biomarkers are still lacking. Key Message: The identification and characterization of
\end{abstract}

G.R.T. and D.S. contributed equally to this work.

\section{KARGER}

๑) 2019 S. Karger AG, Basel

E-Mail karger@karger.com

www.karger.com/che additional co-inhibitory pathways as novel pharmacological targets to improve the clinical response in refractory patients has led to the development of different immune checkpoint inhibitors, the activities of which are currently under investigation. In this review, we discuss recent literature data concerning the mechanisms of action of next-generation monoclonal antibodies targeting LAG-3, TIM-3, and TIGIT co-inhibitory molecules that are being explored in clinical trials, as single agents or in combination with other immune-stimulating agents.

(c) 2019 S. Karger AG, Basel

\section{Introduction}

Immune Checkpoint Therapy Overview

The immune checkpoint (ICK) therapy is an emerging approach to oncological treatment, which is increasingly used for a variety of cancers. This strategy relies on the modulation of regulatory pathways that physiologically
Grazia R. Tundo

Department of Clinical Sciences and Translational Medicine, University of Rome Tor Vergata

Via Montpellier 1IT-00133 Rome (Italy)

E-Mail grazia.tundo@libero.it

Grazia Graziani

Department of Systems Medicine, University of Rome Tor Vergata

Via Montpellier 1

IT-00133 Rome (Italy)

E-Mail graziani@uniroma2.it 
suppress excessive and potentially harmful activation of $\mathrm{T}$ lymphocytes during the immune response in order to enhance their natural antitumour activity [1]. Conceptually, the introduction of biological drugs acting on ICKs into clinical practice has represented a key change in the therapeutic approach of cancer, since the target moves from malignant cells to healthy $\mathrm{T}$ cells with the ultimate aim of killing tumours by immune-mediated mechanisms. Ipilimumab, a fully human monoclonal antibody (mAb) which targets CTLA-4, a negative regulator of CD28-dependent T-cell responses (Appendix) [2], was the first ICK inhibitor (ICKi) approved by the FDA and EMA in 2011 [3, 4] for patients with metastatic/unresectable melanoma $[5,6]$. Ipilimumab also represented the first systemic therapy able to prolong overall survival (OS) in patients with advanced-stage melanoma, more than 30 years following the approval of dacarbazine, a chemotherapeutic agent considered to be the reference drug, although responses were $<15 \%$ and generally transient [7]. Pooled analysis of survival rates indicated that approximately $20 \%$ of all melanoma patients treated with ipilimumab survived for up to 10 years [8], while $<2 \%$ of dacarbazine-treated patients survived for more than 5 years [9]. However, the majority of patients did not obtain a long-lasting clinical benefit from ipilimumab when used as a single agent. The clinical success of the antiCTLA-4 mAb has markedly stimulated the development of other ICKi, which in recent years led to the approval of mAbs against the PD-1/PD-L1 axis (Appendix; i.e., the anti-PD-1 mAbs nivolumab, pembrolizumab, and cemiplimab, and the anti-PD-L1 mAbs atezolizumab, durvalumab, and avelumab) [10-12] (Table 1). Even though CTLA-4 and PD-1/PD-L1 seem to cover similar inhibitory effects on T-cell activity (such as the inhibition of Tcell proliferation and survival, reduction in IL-2 and IFN $-\gamma$ release), they bear distinct profiles of expression and intracellular signalling, and they have non-overlapping biological activity [13] (Appendix). Indeed, for metastatic melanoma, both nivolumab and pembrolizumab showed superior OS and response rates compared to ipilimumab alone [14-17]. Starting from 2014, nivolumab and pembrolizumab were FDA/EMA approved, initially for previously treated, and then for untreated advanced melanoma patients, replacing ipilimumab in the first-line setting. Moreover, combination therapies based on the synergistic blockade of CTLA-4 and PD-1/PD-L1 pathways resulted in enhanced antitumour activity in preclinical mouse models in comparison to either regimen [18]. Indeed, the results of phase III studies showed significantly improved clinical outcomes when nivolumab was

Immune Checkpoint Inhibitors Targeting Lag-3, TIM-3, and TIGIT combined with ipilimumab as compared to the singleagent regimen, the 3 -year survival rates being 58,52 , and $34 \%$ in the nivolumab-plus-ipilimumab, nivolumab, and ipilimumab arms, respectively $[14,15,19]$. Thus, the FDA (in 2015) and EMA (in 2016) approved ipilimumab plus nivolumab as the first ever ICKi combination therapy for the front-line treatment of wild-type BRAFV600 unresectable or metastatic melanoma. Soon after, the indication of nivolumab-ipilimumab combination was extended by FDA to include previously untreated BRAF-mutated melanoma [20]. The introduction of ICKi in clinical practice has also improved survival in patients with other cancer types. Indeed, ICKi are currently approved for a variety of solid tumours, as single agents and in some cases in combination with another ICKi or with chemotherapy (Table 1) [21-24]. Interestingly, pembrolizumab also received FDA approval for the treatment of adult and paediatric patients with unresectable or metastatic solid tumours characterized by microsatellite instability-high (MSI-H) or mismatch repair deficiency (dMMR; Table 1). This represented the first tissue/site agnostic indication of an anticancer drug, based on a tumour biomarker status, rather than on tumour histology. The rationale for using ICKi for MSI/dMMR tumours is based on their elevated mutational burden, which results in the production of a wide repertoire of non-self-antigenic peptides, which in turn can be efficiently targeted by a hyperstimulated immune system [25-29].

ICKi in the Context of the Tumour Microenvironment A critical aspect in determining the success of ICKi-based therapies regards the increased survival and activation of tumour-infiltrating lymphocytes (TILs) [1]. The T-cell response is an extremely complex process that is enabled through the interaction of both inhibitory and stimulatory signalling pathways coming from cells of different lineages present in the same microenvironment. In cancer progression, tumour microenvironment (TME) is a phenotypic expression of the cross-talk between tumour and healthy host cells, mostly immune cells. A specific TME composition is the result of a vast repertoire of cytokines, soluble-factors, and biological active fragments that orchestrate extracellular matrix (ECM) remodelling and architecture, by affecting cell motility, polarity, and differentiation (in particular epithelial-mesenchymal transition). These factors are either synthesized/secreted by malignant and non-malignant cells or released, upon enzymatic shedding, from structural and non-structural extracellular matrix components (i.e., the tumstatin, canstatin, and arrestin fragments of collagen IV and 
Table 1. Approved therapeutic uses of anti-CTLA-4 and anti-PD-1 or anti-PDL-1 mAbs

\begin{tabular}{|c|c|c|c|}
\hline Target & $\mathrm{mAb}$ & FDA approved indication (year of approval) & EMA approved indication (year of approval) \\
\hline \multirow[t]{3}{*}{ CTLA-4 } & \multirow[t]{3}{*}{ Ipilimumab } & Unresectable or metastatic melanoma (2011) & $\begin{array}{l}\text { Unresectable or metastatic melanoma in adults who have received } \\
\text { prior therapy (2011) }\end{array}$ \\
\hline & & Adjuvant treatment for stage III melanoma (2015) & $\begin{array}{l}\text { First-line treatment of unresectable or metastatic melanoma in } \\
\text { adults (2013) }\end{array}$ \\
\hline & & Unresectable or metastatic melanoma in paediatric patients ( $\geq 12$ years) (2017) & $\begin{array}{l}\text { Unresectable or metastatic melanoma in adults and adolescents } \\
\text { ( } \geq 12 \text { years) (2017) }\end{array}$ \\
\hline \multirow[t]{11}{*}{ PD-1 } & \multirow[t]{11}{*}{ Nivolumab } & $\begin{array}{l}\text { BRAF V600 wild-type and BRAF V600 mutation positive unresectable or advanced melanoma } \\
\text { in previously treated patients (2014) }\end{array}$ & Unresectable or metastatic melanoma in adults (2015) \\
\hline & & $\begin{array}{l}\text { Metastatic squamous NSCLC that progressed during or after platinum-based chemotherapy } \\
\text { (2015) }\end{array}$ & $\begin{array}{l}\text { Locally or advanced NSCLC previously treated with chemotherapy } \\
\text { (2016) }\end{array}$ \\
\hline & & $\begin{array}{l}\text { Metastatic NSCLC (including non-squamous) that progressed during or after platinum-based } \\
\text { chemotherapy (2015) }\end{array}$ & Advanced renal cell carcinoma after prior therapy in adults (2016) \\
\hline & & Metastatic renal cell carcinoma patients who have received prior antiangiogenic therapy (2015) & $\begin{array}{l}\text { Relapsed or refractory classical Hodgkin lymphoma after autologous } \\
\text { hematopoietic stem cell transplantation (auto-HSCT) and treatment } \\
\text { with brentuximab vedotin (2016) }\end{array}$ \\
\hline & & $\begin{array}{l}\text { Classical Hodgkin lymphoma relapsed or progressed after: (a) auto-HSCT and brentuximab } \\
\text { vedotin, (b) } 3 \text { or more lines of systemic therapy that includes auto-HSCT (2016) }\end{array}$ & $\begin{array}{l}\text { Locally or metastatic urothelial cancer cannot be surgically removed } \\
\text { or previously treated with platinum-based chemotherapy (2017) }\end{array}$ \\
\hline & & $\begin{array}{l}\text { Recurrent or metastatic squamous cell carcinoma of the head and neck with disease progression } \\
\text { on or after platinum-based therapy (2016) }\end{array}$ & $\begin{array}{l}\text { Metastatic squamous cell cancer of the head and neck previously } \\
\text { treated with platinum-based chemotherapy (2017) }\end{array}$ \\
\hline & & $\begin{array}{l}\text { Locally advanced or metastatic urothelial carcinoma that progressed: (a) during or following } \\
\text { platinum-containing chemotherapy; (b) within } 12 \text { months of neoadjuvant or adjuvant } \\
\text { platinum-containing chemotherapy (2017) }\end{array}$ & $\begin{array}{l}\text { Adjuvant therapy in melanoma with lymph node involvement or } \\
\text { metastatic disease after complete resection (2018) }\end{array}$ \\
\hline & & $\begin{array}{l}\text { Adult and paediatric ( } \geq 12 \text { years) patients with MSI-H or dMMR metastatic colorectal cancer } \\
\text { that progressed following treatment with a fluoropyrimidine, oxaliplatin, and irinotecan (2017) }\end{array}$ & \\
\hline & & Hepatocellular carcinoma previously treated with sorafenib (2017) & \\
\hline & & $\begin{array}{l}\text { Adjuvant therapy in melanoma with lymph node involvement or metastatic disease after } \\
\text { complete resection (2017) }\end{array}$ & \\
\hline & & Metastatic small cell lung cancer that has progressed after platinum-based chemotherapy (2018) & \\
\hline \multirow{4}{*}{$\begin{array}{l}\text { CTLA-4 } \\
\text { PD-1 }\end{array}$} & \multirow{4}{*}{$\begin{array}{l}\text { Ipilimumab } \\
\text { plus nivolumab }\end{array}$} & BRAF V600 wild-type unresectable or metastatic melanoma (2015) & Unresectable or metastatic melanoma in adults (2016) \\
\hline & & $\begin{array}{l}\text { BRAF V600 wild-type and BRAF V600 mutation-positive unresectable or metastatic melanoma } \\
\text { (benefit in low tumour PDL-1 expression) (2016) }\end{array}$ & Intermediate poor-risk advanced renal cell carcinoma (2018) \\
\hline & & First-line treatment of intermediate/poor-risk advanced renal cell carcinoma (2018) & \\
\hline & & $\begin{array}{l}\text { Adult and paediatric patients ( } \geq 12 \text { years) with MSI-H or dMMR metastatic colorectal cancer } \\
\text { that has progressed after treatment with a fluoropyrimidine, oxaliplatin, and irinotecan (2018) }\end{array}$ & \\
\hline \multirow[t]{9}{*}{ PD-1 } & \multirow[t]{9}{*}{ Pembrolizumab } & $\begin{array}{l}\text { Unresectable or metastatic melanoma patients who are no longer responding to other drugs } \\
\text { (2014) }\end{array}$ & Unresectable or metastatic melanoma (2015) \\
\hline & & $\begin{array}{l}\text { Advanced metastatic NSCLC with high PDL-1 expression (tumour proportion score [TPS] } \\
\geq 1 \% \text { ) that has progressed after other treatments }(2015)\end{array}$ & $\begin{array}{l}\text { Locally advanced or metastatic non-squamous NSCLC expressing } \\
\text { PDL-1 (TPS } \geq 1 \% \text { ) after at least one prior chemotherapy regimen } \\
(2016)\end{array}$ \\
\hline & & First-line treatment of unresectable or metastatic melanoma (2015) & $\begin{array}{l}\text { First-line treatment of metastatic NSCLC with no EGFR or ALK- } \\
\text { positive mutations expressing PD-L1 (TPS } \geq 50 \%)(2016)\end{array}$ \\
\hline & & $\begin{array}{l}\text { Recurrent or metastatic head and neck squamous cell carcinoma with disease progression on or } \\
\text { after platinum-containing chemotherapy (2016) }\end{array}$ & $\begin{array}{l}\text { Refractory classical Hodgkin lymphoma after failure of auto-HSCT } \\
\text { and brentuximab vedotin, or transplant-ineligible and after failure } \\
\text { of brentuximab vedotin (2017) }\end{array}$ \\
\hline & & $\begin{array}{l}\text { First-line treatment of metastatic NSCLC with no EGFR or ALK genomic tumour aberrations } \\
\text { with high PD-L1 expression (TPS } \geq 50)(2016)\end{array}$ & $\begin{array}{l}\text { Locally advanced or metastatic urothelial carcinoma not eligible for } \\
\text { cisplatin-containing chemotherapy and expressing PD-L1 } \\
\text { (combined positive score }[\mathrm{CPS}] \geq 10)(2018)\end{array}$ \\
\hline & & $\begin{array}{l}\text { Adult and paediatric refractory classical Hodgkin lymphoma relapsed after three or more prior } \\
\text { lines of therapy (2017) }\end{array}$ & $\begin{array}{l}\text { Locally advanced or metastatic urothelial carcinoma after platinum- } \\
\text { containing chemotherapy (2018) }\end{array}$ \\
\hline & & $\begin{array}{l}\text { First-line treatment of metastatic non-squamous NSCLC (in combination with pemetrexed and } \\
\text { carboplatin) irrespective of tumour PD-L1 expression status (2017) }\end{array}$ & $\begin{array}{l}\text { First-line treatment of metastatic non-squamous NSCLC with no } \\
\text { EGFR or ALK-positive mutations (in combination with pemetrexed } \\
\text { and platinum chemotherapy) (2018) }\end{array}$ \\
\hline & & $\begin{array}{l}\text { Locally advanced or metastatic urothelial carcinoma ineligible for cisplatin-containing } \\
\text { chemotherapy or progressed during or following platinum-containing chemotherapy or within } \\
12 \text { months of neoadjuvant or adjuvant treatment with platinum-containing chemotherapy } \\
\text { (2017) }\end{array}$ & $\begin{array}{l}\text { Recurrent or metastatic head and neck squamous cell carcinoma } \\
\text { expressing PD-L1 (TPS } \geq 50 \% \text { ), and progressing on or after } \\
\text { platinum-containing chemotherapy (2018) }\end{array}$ \\
\hline & & Adult and paediatric unresectable or metastatic solid tumour with MSI-H or dMMR (2017) & $\begin{array}{l}\text { Adjuvant treatment of adults with stage III melanoma and lymph } \\
\text { node involvement after complete resection (2018) }\end{array}$ \\
\hline
\end{tabular}


Table 1 (continued)

\begin{tabular}{|c|c|c|c|}
\hline Target & $\mathrm{mAb}$ & FDA approved indication (year of approval) & EMA approved indication (year of approval) \\
\hline & & $\begin{array}{l}\text { Recurrent locally advanced or metastatic gastric or gastroesophageal junction adenocarcinoma } \\
\text { expressing PD-L1 }(\mathrm{CPS} \geq 1) \text { that has progressed on or after two or more prior lines of therapy } \\
\text { including fluoropyrimidine- and platinum-containing chemotherapy and, if appropriate, } \\
\text { HER2/neu-targeted therapy }(2017)\end{array}$ & $\begin{array}{l}\text { First-line treatment of metastatic squamous NSCLC (in } \\
\text { combination with carboplatin and either paclitaxel or nab- } \\
\text { paclitaxel) (2019) }\end{array}$ \\
\hline & & $\begin{array}{l}\text { Recurrent or metastatic cervical cancer with disease progression on or after chemotherapy } \\
(\text { PDL-1 expression, CPS } \geq 1)(2018)\end{array}$ & \\
\hline & & $\begin{array}{l}\text { Adult and paediatric refractory primary mediastinal large B-cell lymphoma, relapsed after two } \\
\text { or more prior lines of therapy (2018) }\end{array}$ & \\
\hline & & $\begin{array}{l}\text { First-line treatment of metastatic non-squamous NSCLC with no EGFR or ALK genomic } \\
\text { tumour aberration (in combination with pemetrexed and platinum chemotherapy) (2018) }\end{array}$ & \\
\hline & & $\begin{array}{l}\text { First line treatment of metastatic squamous NSCLC (in combination with carboplatin and } \\
\text { either paclitaxel or nab-paclitaxel) regardless of tumour PD-L1 expression status (2018) }\end{array}$ & \\
\hline & & Hepatocellular carcinoma previously treated with sorafenib (2018) & \\
\hline & & $\begin{array}{l}\text { Adult and paediatric patients with recurrent locally advanced or metastatic Merkel cell } \\
\text { carcinoma (2018) }\end{array}$ & \\
\hline & & $\begin{array}{l}\text { Adjuvant treatment of patients with melanoma with involvement of lymph node(s) following } \\
\text { complete resection (2019) }\end{array}$ & \\
\hline & & $\begin{array}{l}\text { First-line treatment of stage III NSCLC not candidate for surgical resection or definitive } \\
\text { chemo-radiation, or metastatic NSCLC expressing PD-L1 (CPS } \geq 1 \% \text { ), with no EGFR or ALK } \\
\text { genomic tumour aberrations (2019) }\end{array}$ & \\
\hline & & $\begin{array}{l}\text { First-line treatment of patients with advanced renal cell carcinoma in combination with the } \\
\text { tyrosine kinase inhibitor axitinib (2019) }\end{array}$ & \\
\hline PD-1 & Cemiplimab & $\begin{array}{l}\text { Metastatic or locally advanced cutaneous squamous cell carcinoma not eligible for curative } \\
\text { surgery or curative radiation (2018) }\end{array}$ & \\
\hline \multirow[t]{7}{*}{ PD-L1 } & \multirow[t]{7}{*}{ Atezolizumab } & $\begin{array}{l}\text { Locally advanced or metastatic urothelial carcinoma that has progressed during or following } \\
\text { any platinum-containing chemotherapy, or within } 12 \text { months of neoadjuvant or adjuvant } \\
\text { chemotherapy (2016) }\end{array}$ & $\begin{array}{l}\text { Advanced or metastatic urothelial carcinoma after prior platinum- } \\
\text { containing chemotherapy, or cisplatin ineligible with PDL-1 } \\
\text { expression covering } \geq 5 \% \text { tumour area (2017) }\end{array}$ \\
\hline & & $\begin{array}{l}\text { Metastatic NSCLC with disease progression during or following platinum-containing } \\
\text { chemotherapy or having progressed on kinase inhibitors if EGFR or ALK mutations are present } \\
(2016)\end{array}$ & \multirow[t]{6}{*}{$\begin{array}{l}\text { Locally advanced or metastatic NSCLC after prior chemotherapy or } \\
\text { that has progressed on kinase inhibitors if EGFR or ALK mutations } \\
\text { are present (2018) }\end{array}$} \\
\hline & & $\begin{array}{l}\text { Locally advanced or metastatic urothelial carcinoma not eligible for cisplatin chemotherapy } \\
\text { (2017) }\end{array}$ & \\
\hline & & $\begin{array}{l}\text { Urothelial carcinoma not eligible for cisplatin therapy and with PDL-1 expression covering } \\
\geq 5 \% \text { tumour area (2018) }\end{array}$ & \\
\hline & & $\begin{array}{l}\text { First-line treatment of metastatic non-squamous NSCLC with no EGFR or ALK mutations, in } \\
\text { combination with bevacizumab, paclitaxel, and carboplatin (2018) }\end{array}$ & \\
\hline & & $\begin{array}{l}\text { Unresectable locally advanced or metastatic triple-negative breast cancer expressing PD-L1, in } \\
\text { combination with nab-paclitaxel (2019) }\end{array}$ & \\
\hline & & $\begin{array}{l}\text { First-line treatment of previously untreated extensive-stage small cell lung cancer in } \\
\text { combination with carboplatin and etoposide (2019) }\end{array}$ & \\
\hline \multirow[t]{2}{*}{ PD-L1 } & \multirow[t]{2}{*}{ Avelumab } & Metastatic Merkel cell carcinoma in adults and paediatric patients ( $\geq 12$ years) (2017) & \multirow[t]{2}{*}{ Metastatic Merkel cell carcinoma in adults (2017) } \\
\hline & & $\begin{array}{l}\text { Locally advanced or metastatic urothelial carcinoma that progressed during or following } \\
\text { platinum-containing chemotherapy or within } 12 \text { months of neoadjuvant or adjuvant platinum- } \\
\text { containing chemotherapy (2017) }\end{array}$ & \\
\hline \multirow[t]{2}{*}{$\mathrm{PD}-\mathrm{L} 1$} & \multirow[t]{2}{*}{ Durvalumab } & $\begin{array}{l}\text { Locally advanced or metastatic urothelial carcinoma that progressed during or following } \\
\text { platinum-containing chemotherapy, or within } 12 \text { months of receiving platinum-containing } \\
\text { neoadjuvant or adjuvant chemotherapy surgery (2017) }\end{array}$ & \multirow[t]{2}{*}{$\begin{array}{l}\text { Locally advanced, unresectable NSCLC expressing PD-L1 } \geq 1 \% \text { that } \\
\text { has not progressed following platinum-based chemotherapy and } \\
\text { radiation therapy (2018) }\end{array}$} \\
\hline & & $\begin{array}{l}\text { Unresectable stage III NSCLC that has not progressed after treatment with platinum-based } \\
\text { chemotherapy and radiation therapy (2018) }\end{array}$ & \\
\hline
\end{tabular}

VEGF released from the matrix reservoir) or cell surface proteins (i.e., cytokine/growth factor receptors, adhesion molecules, dystroglycan) [30-34]. In this respect, the pattern of proteolytic enzymes, especially matrix metalloproteinases, released by cancer, immune, and resident cells contribute to the establishment of a tumour-specific TME, as extensively reviewed elsewhere [32, 33, 35].
Thus, TME components tightly affect tumour growth or dissemination and immune responses, and probably also the immunotherapy outcome. For instance, tumour-infiltrating macrophage (TAM) polarization is highly dependent on the type of cytokines produced in the TME, which may determine the generation of pro-inflammatory and tumouricidal M1 or of pro-tumoural M2 TAMs 
[36]. The latter, besides directly promoting tumour growth and metastasis through the secretion of matrix metalloproteinases, growth factors, and angiogenic factors, efficiently suppress immune effector functions by producing cytokines and enzymes, which directly or indirectly suppress effector cells [37]. Interestingly, the cross-talk between T cells and TAMs [38] may result in a dual opposite effect: (a) increased recruitment of cytotoxic T cells sustained by M1 TAMs cytokines/chemokines; (b) blockade of cytotoxic T-cell activity by M2 TAMs. Since the M2-induced negative feedback pathway on T cells can hamper the efficacy of immunotherapies, it has been suggested that inhibition of M2 TAMs, by targeting specific receptors expressed in these cells (e.g., VEGFR-1), might improve ICKi efficacy [39-42]. Therefore, the extreme heterogeneity of TME composition makes it hard to decipher how a given TME drives the immune response to cancer and, consequently, how it may affect the overall efficacy of ICKi [43].

\section{The Future of ICK Therapy}

Despite the success of the ICK blockade, many questions remain unsolved. This might account for the evidence that clinical benefit is limited to a subset of patients for each cancer type and, additionally, responders often develop resistance to treatment [44]. Due to the dynamic nature and complexity of the immune response, there is increasing interest in understanding the molecular mechanisms of "novel" immunomodulatory pathways and the molecular bases of the ICK interplay. The combination of ICKi either with ICKi targeting different immune regulatory pathways or with conventional anticancer therapy (chemotherapy and radiotherapy) has emerged as a promising approach to improving clinical benefit. Moreover, immune-directed strategies hitting different TME components that regulate the multifaceted aspects of cancer interaction are currently under investigation [45-47]. The main "novel" ICKs that are involved at different steps in immune antitumour responses include either positive or negative modulators. Negative modulators are LAG-3, TIM-3, TIGIT, VISTA, B7-H3, and BTLA, which assist the CTLA-4 and PD-1/PD-L1 pathways in turning off the physiological immune response, albeit with some variability which has emerged depending on the model [22, 44]. Conversely, immune activators include, among others, ICOS, a member of the CD28-superfamily expressed in activated T cells [48], and CD40, a member of the TNF receptor superfamily, which is expressed in a number of cells of the innate and adaptive immunity as well as in B lymphocytes [49]. Glucocorticoid-induced tumour ne- crosis factor receptor-related (GITR) is another co-stimulatory molecule of clinical interest. In fact, anti-GITR agonistic mAbs, which induce activation of CD8+ effector function and inhibition of tumour-infiltrating T-regulatory cells (Tregs), are investigated in phase I/II trials [50]. Actually, TME Tregs play a pivotal role in cancer cell escape from immune surveillance and the expression of co-inhibitory molecules, such as CTLA-4, PD-1, LAG-3, TIM-3, and TIGIT (see below), on their surface is critical for their suppressive functions [51]. Other T-cell co-stimulatory receptors that have been targeted by agonist $\mathrm{mAbs}$ in clinical development include CD27, OX-40, 4-1BB, and TWEAK [52-54].

Here, we review the biological functions and molecular features of LAG-3, TIM-3, and TIGIT, three wellstudied novel ICKs that strictly co-operate with CD28/ CTLA-4 and PD-1/PD-L1 axes to modulate the cancer immune response. An update on the clinical development of agents targeting these ICKs (e.g., mAbs including bispecific antibodies, recombinant fusion proteins) is also presented (Table 2).

\section{Lymphocyte Activation Gene-3 (LAG-3, CD223)}

\section{Structural Molecular Features and Signal}

Transduction of LAG-3

Lymphocyte activation gene-3 (LAG-3 or CD223) is a promising ICK, which physiologically suppresses T-cell activation and cytokine secretion. LAG-3 is a single transmembrane protein with three Ig extracellular domains that is expressed on activated $\mathrm{CD}_{4}^{+}$and $\mathrm{CD}^{+} \mathrm{T}$ cells, Tregs, B cells, natural killer (NK), and dendritic cells (DC) [55-61]. Even though the amino acid sequence homology is less than 20\%, LAG-3 shares high structural homology with CD4 and both genes are located proximally on human chromosome 12 (12p13) [61, 62]. Like CD4, LAG-3 binds to major histocompatibility complex MHC class II (MHC-II) molecules (Fig. 1), although its $\mathrm{Kd}\left(6 \times 10^{-8} \mathrm{M}\right)$ is several orders of magnitude higher than that of CD4 $\left(10^{-4} \mathrm{M}\right)[63,64]$. Surprisingly, despite the high affinity, only a handful of residues located on the D1 loop are involved in MHC-II and LAG-3 binding, in contrast to the extensive molecular interaction between MHC-II and CD4 $[65,66]$.

Several studies initially performed in cellular in vitro models and then confirmed in murine models revealed that the interaction between LAG-3 and MHC-II hinders the MHC-II binding to the T-cell receptor (TCR) and CD4, thus directly suppressing the TCR signalling and 
Table 2. Clinical trials with next-generation ICKi

\begin{tabular}{|c|c|c|c|c|c|c|}
\hline Target & Drug & Combined agent & NCT identifier & Phase & Status & Setting \\
\hline \multirow[t]{31}{*}{ LAG-3 } & $\begin{array}{l}\text { Eftilagimod alpha (IMP321) } \\
\text { (soluble LAG-3 Ig) }\end{array}$ & - & NCT00732082 [98] & I & Terminated & $\begin{array}{l}\text { Unresectable pancreatic cancer receiving first-line gem- } \\
\text { citabine }\end{array}$ \\
\hline & & - & NCT00349934 [100] & I & Completed & Metastatic breast carcinoma \\
\hline & & - & NCT00351949 [97] & I & Completed & Renal cell carcinoma \\
\hline & & Melan-A VLP vaccine & NCT00324623 [99] & I & Completed & Melanoma \\
\hline & & - & NCT03252938 & I & Recruiting & Solid tumours \\
\hline & & Pembrolizumab & NCT02676869 & I & $\begin{array}{l}\text { Active, not } \\
\text { recruiting }\end{array}$ & Unresectable or metastatic melanoma \\
\hline & & Paclitaxel & NCT02614833 & $\mathrm{I} / \mathrm{II}$ & Recruiting & Hormone receptor-positive metastatic breast cancer \\
\hline & & Pembrolizumab & NCT03625323 & II & Recruiting & NSCLC and head and neck carcinoma \\
\hline & Relatlimab & $\begin{array}{l}\text { Nivolumab and urelumab } \\
\text { (anti-CD137) }\end{array}$ & NCT02658981 & I & Recruiting & Recurrent glioblastoma \\
\hline & & Nivolumab & NCT02966548 & I & Recruiting & Advanced solid tumours \\
\hline & & $\begin{array}{l}\text { Nivolumab, carboplatin, } \\
\text { paclitaxel, radiotherapy }\end{array}$ & NCT03044613 & I & Recruiting & $\begin{array}{l}\text { Neoadjuvant treatment of stage II/III oesophageal/gastro- } \\
\text { esophageal junction cancer }\end{array}$ \\
\hline & & Nivolumab & NCT03493932 & I & Recruiting & Recurrent glioblastoma \\
\hline & & Nivolumab & $\begin{array}{l}\text { NCT01968109 } \\
{[102,103]}\end{array}$ & $\mathrm{I} / \mathrm{II}$ & Recruiting & Unresectable and metastatic solid tumours \\
\hline & & Nivolumab & NCT02061761 & $\mathrm{I} / \mathrm{II}$ & Recruiting & Relapsed hematologic malignancies \\
\hline & & $\begin{array}{l}\text { Nivolumab, ipilimumab, } \\
\text { daratumumab (anti-CD38) }\end{array}$ & NCT02488759 & $\mathrm{I} / \mathrm{II}$ & Recruiting & Virus-associated tumours \\
\hline & & $\begin{array}{l}\text { Nivolumab and BMS-986205 } \\
\text { (IDO1 inhibitor) or } \\
\text { nivolumab and ipilimumab }\end{array}$ & NCT03459222 & $\mathrm{I} / \mathrm{II}$ & Recruiting & Advanced/metastatic solid tumours \\
\hline & & Nivolumab & NCT03610711 & $\mathrm{I} / \mathrm{II}$ & $\begin{array}{l}\text { Not yet } \\
\text { recruiting }\end{array}$ & Recurrent or metastatic oesophageal-gastric cancer \\
\hline & & $\begin{array}{l}\text { Ipilimumab, nivolumab, } \\
\text { conventional surgery }\end{array}$ & NCT02519322 & II & Recruiting & Unresectable stage IIIB-IV melanoma \\
\hline & & Nivolumab & NCT03607890 & II & Recruiting & MSI-H solid tumours refractory to prior PD-L1 therapy \\
\hline & & Nivolumab & NCT03623854 & II & $\begin{array}{l}\text { Not yet } \\
\text { recruiting }\end{array}$ & Advanced chordoma \\
\hline & & Nivolumab & NCT03642067 & II & Recruiting & $\begin{array}{l}\text { Metastatic or locally advanced micro- } \\
\text { satellite stable (MSS) colorectal cancer }\end{array}$ \\
\hline & & Nivolumab & NCT03743766 & II & Recruiting & $\begin{array}{l}\text { Unresectable or metastatic melanoma patients who have not } \\
\text { received prior treatment with immunotherapy }\end{array}$ \\
\hline & & Nivolumab & NCT 03470922 & $\mathrm{II} / \mathrm{III}$ & Recruiting & $\begin{array}{l}\text { Unresectable or metastatic melanoma patients who have not } \\
\text { received prior treatment with immunotherapy }\end{array}$ \\
\hline & LAG525 (mAb) & $\begin{array}{l}\text { Spartalizumab (anti-PD-1), } \\
\text { NIR178 (adenosine A2A } \\
\text { receptor antagonist), } \\
\text { capmatinib (c-met inhibitor), } \\
\text { MCS110 (anti-M-CSF), } \\
\text { canakinumab (anti-IL-1 } \beta \text { ) }\end{array}$ & NCT03742349 & I & Recruiting & Triple negative breast cancer \\
\hline & & Spartalizumab & NCT02460224 & $\mathrm{I} / \mathrm{II}$ & $\begin{array}{l}\text { Active not } \\
\text { recruiting }\end{array}$ & Advanced tumours \\
\hline & & Spartalizumab & NCT03365791 & II & $\begin{array}{l}\text { Active not } \\
\text { recruiting }\end{array}$ & $\begin{array}{l}\text { Advanced solid and haematological } \\
\text { malignancies }\end{array}$ \\
\hline & Sym022 (mAb) & - & NCT03489369 & I & Recruiting & $\begin{array}{l}\text { Advanced/unresectable or metastatic solid tumour or lym- } \\
\text { phomas refractory to } \\
\text { available therapy }\end{array}$ \\
\hline & & $\begin{array}{l}\text { Sym021 (anti-PD-1) and } \\
\text { Sym023 (anti-TIM3) }\end{array}$ & NCT03311412 & I & Recruiting & Advanced solid tumours or lymphomas \\
\hline & INCAGN02385 (mAb) & - & NCT03538028 & I & Recruiting & Advanced malignancies \\
\hline & REGN3767 (mAb) & REGN2810 (anti-PD-1) & NCT03005782 & I & Recruiting & $\begin{array}{l}\text { Advanced malignancies including } \\
\text { lymphoma }\end{array}$ \\
\hline & TSR-033 (mAb) & Anti-PD-1 & NCT03250832 & I & Recruiting & Advanced solid tumours \\
\hline
\end{tabular}


Table 2 (continued)

\begin{tabular}{|c|c|c|c|c|c|c|}
\hline Target & Drug & Combined agent & NCT identifier & Phase & Status & Setting \\
\hline & $\begin{array}{l}\text { MGD013 (PD-1/LAG-3 } \\
\text { bispecific mAb) }\end{array}$ & - & NCT03219268 & I & Recruiting & Advanced solid tumours and haematological malignancies \\
\hline & $\begin{array}{l}\text { FS118 (LAG-3/PD-L1 } \\
\text { bispecific mAb) }\end{array}$ & - & NCT03440437 & I & Recruiting & $\begin{array}{l}\text { Tumours that have progressed on or after prior PD-1/ } \\
\text { PD-L1-containing therapy }\end{array}$ \\
\hline & $\begin{array}{l}\text { BMS- } 986213 \text { (fixed dose } \\
\text { combination of relatlimab } \\
\text { and nivolumab) }\end{array}$ & Chemotherapy & NCT03662659 & II & Recruiting & Gastric or gastroesophageal junction adenocarcinoma \\
\hline \multirow[t]{10}{*}{ TIM-3 } & \multirow[t]{2}{*}{ Sym023 (mAb) } & - & NCT03489343 & I & Recruiting & $\begin{array}{l}\text { Advanced/unresectable or metastatic solid tumour or lym- } \\
\text { phomas that are refractory to available therapy or for which } \\
\text { no standard therapy is available }\end{array}$ \\
\hline & & $\begin{array}{l}\text { Sym021 (anti-PD-1) and/or } \\
\text { Sym022 }\end{array}$ & NCT03311412 & I & Recruiting & $\begin{array}{l}\text { Advanced/unresectable or metastatic solid tumour malig- } \\
\text { nancies or lymphomas that are refractory to available thera- } \\
\text { py or for which no standard therapy is available }\end{array}$ \\
\hline & \multirow[t]{2}{*}{ TSR-022 (mAb) } & $\begin{array}{l}\text { An anti-PD-1 mAb } \\
\text { Niraparib (PARP inhibitor); } \\
\text { TSR-042 (anti-PD-1); } \\
\text { carboplatin; paclitaxel; } \\
\text { bevacizumab; pemetrexed }\end{array}$ & $\begin{array}{l}\text { NCT02817633 } \\
\text { NCT03307785 }\end{array}$ & I & $\begin{array}{l}\text { Recruiting } \\
\text { Recruiting }\end{array}$ & $\begin{array}{l}\text { Advanced solid tumours } \\
\text { Metastatic and advanced solid tumours; metastatic and stage } \\
\text { IIIB NSCLC }\end{array}$ \\
\hline & & TSR-042 (anti-PD-1) & NCT03680508 & II & Recruiting & Liver cancer \\
\hline & INCAGN02390 (mAb) & - & NCT03652077 & I & Recruiting & Advanced malignancies \\
\hline & $\begin{array}{l}\text { LY3415244 (anti-PD-L1/ } \\
\text { TIM-3 bispecific Ab) }\end{array}$ & - & NCT03752177 & I & Recruiting & Advanced solid tumours \\
\hline & LY3321367 (mAb) & LY3300054 (anti-PD-1) & NCT03099109 & I & Recruiting & Advanced relapsed/refractory solid tumours \\
\hline & MBG453 (mAb) & $\begin{array}{l}\text { Spartalizumab } \\
\text { Spartalizumab and decitabine }\end{array}$ & $\begin{array}{l}\text { NCT02608268 } \\
\text { NCT03066648 }\end{array}$ & $\begin{array}{l}\text { I } \\
\text { I }\end{array}$ & $\begin{array}{l}\text { Recruiting } \\
\text { Recruiting }\end{array}$ & $\begin{array}{l}\text { Advanced solid tumours } \\
\text { AML and high-risk MDS patients }\end{array}$ \\
\hline & BGB-A425 (mAb) & Tislelizumab (anti-PD-1) & NCT03744468 & I & Recruiting & Advanced solid tumours \\
\hline & $\begin{array}{l}\text { RO7121661 (anti-PD-1/ } \\
\text { TIM-3 bispecific } \mathrm{mAb} \text { ) }\end{array}$ & - & NCT03708328 & I & Recruiting & Advanced and/or metastatic solid tumours \\
\hline \multirow[t]{3}{*}{ TIGIT } & OMP-31M32 (mAb) & Nivolumab & NCT03119428 & I & $\begin{array}{l}\text { Active not } \\
\text { recruiting }\end{array}$ & Locally advanced or metastatic solid tumours \\
\hline & $\mathrm{AB} 154(\mathrm{mAb})$ & $\mathrm{AB} 122$ (anti-PD-1) & NCT03628677 & I & Recruiting & Advanced malignancies \\
\hline & MTIG7192A (mAb) & Atezolizumab & NCT03563716 & II & Recruiting & $\begin{array}{l}\text { Chemotherapy-naïve patients with locally advanced or met- } \\
\text { astatic NSCLC }\end{array}$ \\
\hline
\end{tabular}

preventing activation of immune responses [63, 67-69]. It has been further shown that LAG-3 spatially associates with the TCR/CD3 complex clustered in raft microdomains $[66,70,71]$. A detailed understanding of the LAG3 intracellular signalling pathway is still lacking and this is likely related to the fact that the LAG-3 cytoplasmic tail lacks canonical inhibitory motives (such as immunoreceptor tyrosine-based inhibitory motif [ITIM] and immunoglobulin tyrosine domain [ITT]) present in other immune receptors. In fact, from a structural point of view, the intracellular region consists of three domains: (i) a serine-phosphorylation site, (ii) a unique KIEELE motif, and (iii) a glutamic acid-proline (EP) repeat [67, 69, 72-74]. The KIEELE motif transmits the inhibitory signal and plays a crucial role in LAG-3 negative regulatory function (Fig. 1), since LAG-3 molecules lacking this domain cannot negatively modulate T-cell activity [74].

\section{LAG-3 in Immune Tolerance to Tumours}

The LAG-3 pathway directly regulates the function of $\mathrm{T}$ cells (Fig. 1). In $\mathrm{CD}^{+}$lymphocytes, LAG-3 signalling prevents the entry of T cells in the $S$ phase of the cell cycle, thus arresting $\mathrm{CD} 4^{+}$clone expansion and suppressing cytokine secretion $[60,67]$. However, LAG-3 is also a negative regulator of $\mathrm{CD} 8^{+} \mathrm{T}$ cells, where it is upregulated following antigen stimulation $[68,69,75]$. Interestingly, tumour-infiltrating $\mathrm{CD}^{+}$cells overexpress LAG-3 in various cancer types (i.e., ovarian cancer, renal cancer, and hepatocarcinoma) [76-79], and the LAG-3 blockade increases $\mathrm{CD} 8^{+} \mathrm{T}$-cell effector function independently from $\mathrm{CD}^{+}$T-cell activity [80]. Recently, LAG-3 has been reported to interact with two additional ligands, galectin-3 (Gal-3), a lectin that is secreted by many cells in TME, and liver sinusoidal endothelial cell lectin (LSECtin), a cell surface lectin expressed by cancer cells (Fig. 1) [66]. The 


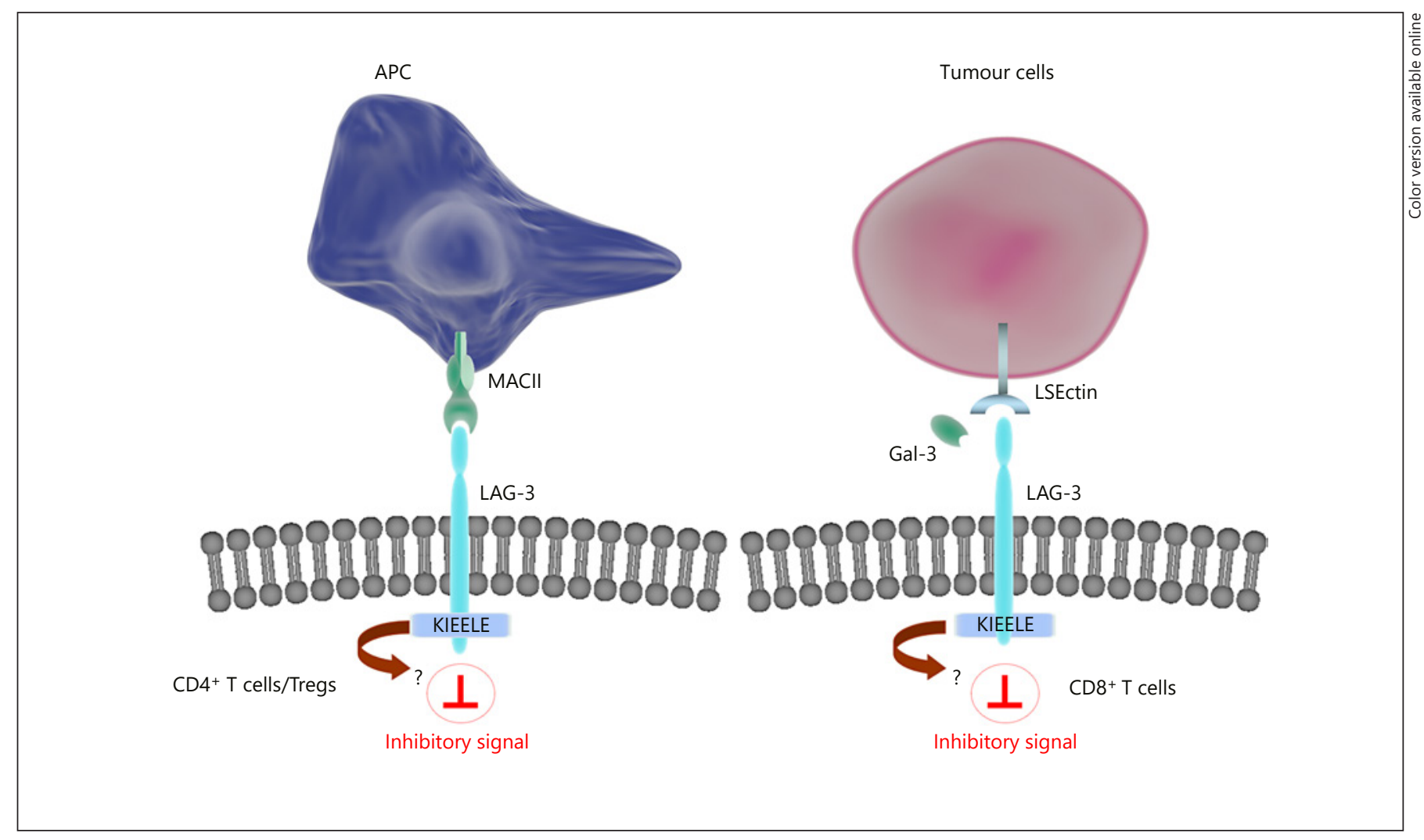

Fig. 1. LAG-3 signalling in TME. LAG-3 is expressed mainly on T and NK cells and binds to MHCII (expressed on APC), Gal-3 (released in TME), and LSECtin (expressed on tumour cells). The LAG-3 cytoplasmic tail contains a non-canonical inhibitor motif KIEELE that mediates an unknown downstream molecular cascade, providing LAG3 with a negative regulatory function (see text for further details).

LAG-3 interaction with these two alternative ligands promotes tumour growth by inhibiting antitumour $\mathrm{CD} 8^{+}-$ dependent responses (Fig. 1) [81-83]. LAG-3 expression is also increased in many tumour-infiltrating Tregs, such as in head and neck squamous small-cell carcinoma and non-small cell lung cancer (NSCLC) [84, 85], and significantly contributes to the suppressive functions of these cells $[59,80]$. In fact, the interaction between the MHC-II expressed on antigen-presenting cells (APCs) with LAG3 on Tregs maximizes the production of immunosuppressive cytokines such as IL-10 and TGF- $\beta$, thus inhibiting cytotoxic T-cell activity [59, 60, 86, 87]. Moreover, this interaction contributes to suppressing DC activation, through the immunoreceptor tyrosine-based activation motif(ITAM)-mediated inhibitory pathway, and to regulating DC homeostasis [58, 88, 89]. Therefore, LAG-3 inhibition might block this suppressive pathway and, consequently, stimulate the antitumour activity of $\mathrm{CD}^{+}$ TILs. LAG-3 exhibits synergistic immunosuppressive ef- fects with other ICKs, mainly with PD-1/PD-L1 [90]. PD-1 and LAG-3, which are co-expressed on the surface of $\mathrm{CD}^{+}$and $\mathrm{CD}^{+}$cells, particularly in TILs, co-operate in regulating $\mathrm{T}$-cell function to promote tumour immune escape $[76,79,91-94]$. The synergistic effect of LAG-3 and PD-1 co-inhibition in enhancing antitumour immunity has been demonstrated using LAG-3 and PD-1 double-KO mice, in which implanted tumours were rejected, whereas in PD-1 KO mice the same tumours only showed a delayed growth $[13,69,95]$. Likewise, a combined blockade of both ICKs by using anti-PD-1 and anti-LAG-3 $\mathrm{mAbs}$ potentiated the immune response against tumours $[13,69,91,95,96]$. Therefore, the available data suggest that therapeutic strategies combining LAG-3 and PD-1 blockers might improve the clinical benefit in different tumour types. Accordingly, a number of phase I/II clinical trials are being carried out to evaluate drug combinations which simultaneously target these two ICKs (Table 2) [69]. 


\section{LAG-3 Targeting in Immunotherapy}

Currently, two main approaches directed against LAG-3 have been developed and are being investigated in different phases of clinical trials: (i) a LAG-3-Ig fusion protein (IMP321 or eftilagimod alpha) and (ii) mAbs which target LAG-3 (BMS-986016 or relatlimab; LAG525 or IMP701; REGN3767; TSR-033; Table 2). Recently, three phase I clinical trials evaluating IMP321 for renal carcinoma, pancreatic adenocarcinoma, and melanoma have been completed with promising results in terms of proliferation and activation of TILs at the tumour site, but not in terms of OS of treated patients [97-99]. The results of another completed phase I clinical trial in metastatic breast carcinoma, reporting a $50 \%$ objective response rate with IMP321 plus paclitaxel versus $25 \%$ with paclitaxel alone [100], have prompted a phase IIb clinical trial that is currently recruiting patients with hormone receptorpositive metastatic breast cancer (NCT02614833). A number of phase I and II clinical trials are recruiting patients to evaluate anti-LAG-3 mAbs as single agents or in combination with chemotherapy, targeted agents, or various anti-PD-1 mAbs (www.clinicaltrials.gov) $[69,90]$ (Table 2). Notably, interim analysis of clinical studies evaluating the first developed anti-LAG-3 antibody (BMS-986016 or relatlimab) with nivolumab in unresectable/metastatic melanoma patients showed promising activity in terms of objective response and disease control rates in patients who were not responsive to previous anti-PD-1 monotherapy. In addition, the response rate was higher in LAG-3-overexpressing tumours $(\geq 1 \%)$ and the safety profile was similar to that of nivolumab monotherapy [101-104]. A phase II trial is currently evaluating the efficacy and safety of relatlimab in combination with nivolumab versus nivolumab alone in previously untreated metastatic/unresectable melanoma. Interestingly, an innovative approach targeting LAG-3 and PD-1 or PDL1 with bispecific mAbs (MGD013 and FS118, respectively) is also undergoing phase I clinical trials (Table 2; www.clinicaltrials.gov) [69].

\section{TIM-3}

Molecular Features, Ligands, and Functions of TIM-3

TIM-3 (T-cell immunoglobulin- and mucin domaincontaining molecule 3 ) is a type I transmembrane protein, identified on the surface of $\mathrm{CD}^{+}$and $\mathrm{CD}^{+}$cells, Tregs, DCs, macrophages, NK cells, B and mast cells. TIM-3 was originally discovered in murine models of autoimmune encephalomyelitis as a negative regulator of the T helper type-1 (Th1) response and Th1-related cytokine expression, such as TNF and INF- $\gamma$ [105-107]. Alteration of the TIM-3 expression profile as well as the TIM-3 blockade result in the exacerbation of autoimmune diseases such as multiple sclerosis, type I diabetes, and rheumatoid arthritis [108-114]. In recent years, corroborating evidence has clarified that TIM-3 further inhibits antitumour immunity, mainly by stimulating $\mathrm{T}$ cell exhaustion and a number of preclinical studies support the hypothesis that modulation of the TIM-3 pathway might improve cancer immunotherapy outcome [115121]. However, controversial tasks regarding the biological role of the TIM-3 signalling pathway still exist, since some studies suggest a stimulatory role of TIM-3 on Tcell function $[114,122]$.

From a structural point of view, TIM-3 is composed of: (i) an extracellular N-terminal $\mathrm{IgV}$ domain followed by a membrane-proximal mucin-like domain that contains O-linked glycosylation sites, and a domain with $\mathrm{N}$ linked glycosylation sites, (ii) a transmembrane domain, and (iii) a C-terminal cytoplasmic tail [114].

The first discovered extracellular ligand of TIM-3 was galectin-9 (gal-9), a $\beta$-galactoside lectin protein that specifically recognizes the structure of $\mathrm{N}$-linked sugar chains in the Tim-3 IgV domain. This ligand is widely expressed in human tumours such as haematological malignancies (Fig. 2). TIM-3/gal-9 interaction has been reported to alter calcium flux and to induce cell death in Th1 cells, thus suppressing their function [109]. Moreover, in colon cancer, tumour-derived gal-9 induces apoptosis of tumourinfiltrating CD8 ${ }^{+}$TILs [123]. However, TIM-3/gal-9 interaction possibly further modulates intracellular signalling by stimulating cytokine production and secretion $[124,125]$. Thus, the biological role of this interaction in T-cell function remains unclear [114].

Phosphatidylserine (PtdSer) is a non-protein ligand of TIM-3 which is exposed on apoptotic cell membranes, and binds the IgV domain of TIM-3 on macrophage surfaces, contributing to the clearance of apoptotic bodies $[126,127]$ (Fig. 2). Another TIM-3 ligand primarily involved in the innate immune response is high-mobility group box 1 (HMGB-1), which is secreted by immune cells as an inflammatory mediator. In TME, HMGB-1 binds to the nucleic acids released from dying cells and mediates their internalization into DC endosome vesicles after binding to receptors for advanced glycation end products (RAGE) and Toll-like receptors, thus triggering natural immunity [128, 129] (Fig. 2). Remarkably, tumour-infiltrating DCs overexpress TIM-3, and this receptor competes with nucleic acids for the binding to 
Fig. 2. TIM-3 signalling in TME. TIM-3 receptor is mainly expressed in $\mathrm{T}, \mathrm{NK}$, and APC cells and binds to four ligands in TME: two soluble molecules, Gal-9 (which specifically recognizes the structure of $\mathrm{N}$ linked sugar chains in the TIM-3 extracellular domain), and HMGB1, and two cell surface molecules, PtdSer, and Ceacam-1. In the absence of ligand, the cytoplasmic tail of TIM-3 binds to Bat3, preventing downstream signalling. Ligand/TIM-3 interaction induces the dissociation of Bat 3 and the phosphorylation of tyrosine residues by Fyn kinase. This event leads to the recruitment of molecular intracellular adaptors (such as p85) and triggers a downstream inhibitory intracellular signalling (see text for further details).

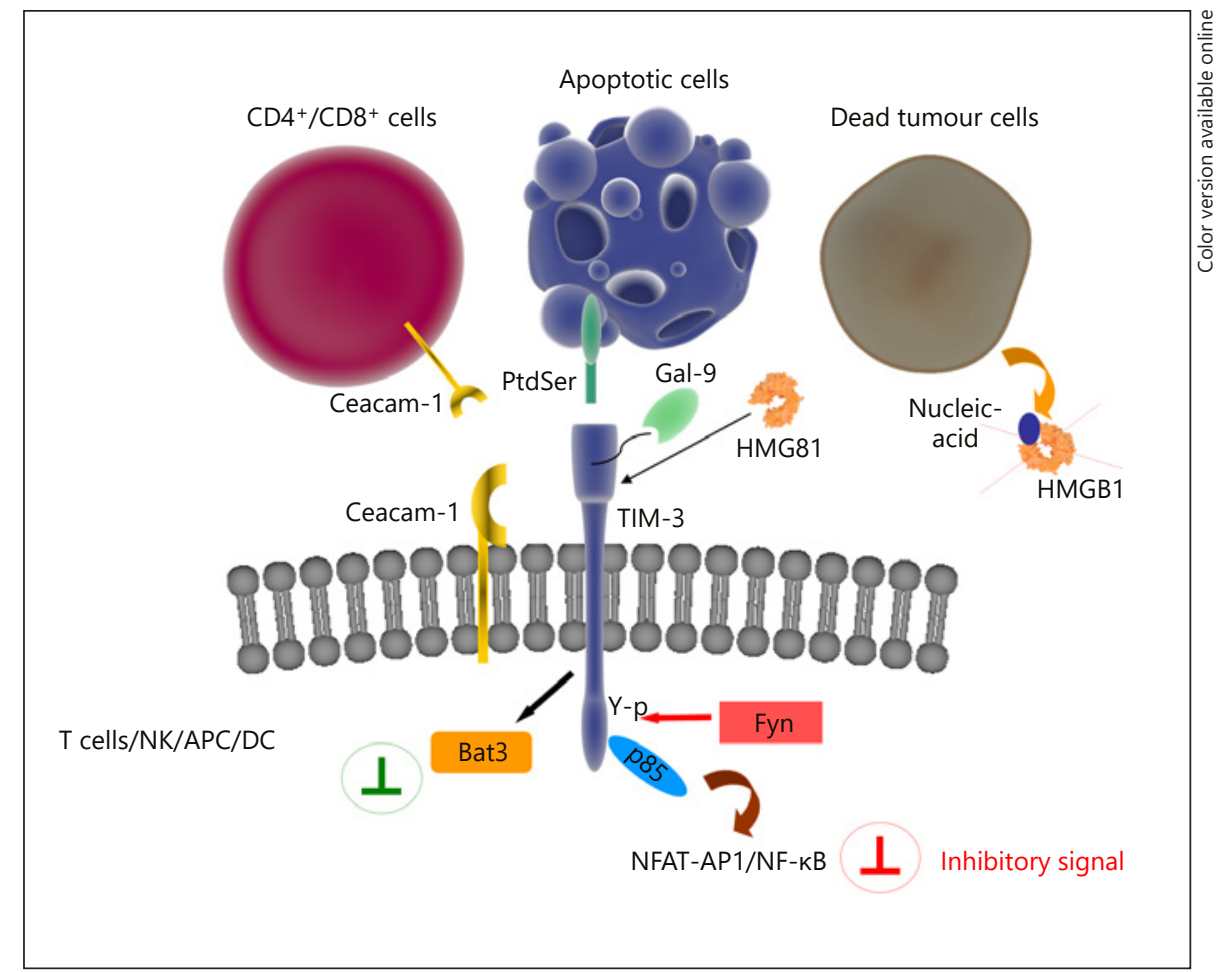

HMGB-1. TIM-3/HMGB-1 interaction inhibits the recruitment of nucleic acids within endosomes, dampening the tumour-derived nucleic acid activation of innate immune response $[129,130]$. The most recently identified TIM-3 ligand is carcinoembryonic antigen cell adhesion molecule 1 (Ceacam-1), a surface molecule that is co-expressed with TIM-3 in $\mathrm{CD}^{+} \mathrm{T}$ cells following tolerance induction, and in exhausted CD8 ${ }^{+}$TILs. Ceacam- 1 facilitates the maturation and stability of TIM-3 through a cisheterodimeric interaction, and stimulates, through cis and/or trans mechanisms, T-cell immune tolerance (Fig. 2) [131]. Even though all the above-described mechanisms may contribute to explaining the immunosuppressive properties of TIM-3, how the binding to its ligands and the cross-talk between the activated pathways exactly impact on the immune response is largely unexplored. Although research into antibodies targeting TIM3 is ongoing in clinical trials, their ability to inhibit the interaction of TIM-3 with its different ligands is not always documented [132].

\section{TIM-3 Intracellular Signalling}

A peculiar structural feature of TIM-3 is that its cytoplasmic tail lacks any known canonical inhibitory sequence, such as ITIM and ITT. Instead, it displays a con- served tyrosine-based motif that mediates the intracellular signalling pathway (Fig. 2) [133]. Several unresolved issues still exist regarding the TCR signalling and the metabolic pathways actually regulated by TIM-3, as emphasized by its pleiotropic activities under the different pathophysiological conditions cited above. In fact, the phosphorylation of 265 and 272 tyrosine residues by different kinases (e.g., Fyn) promotes downstream recruitment of one or more $\mathrm{SH} 2$ domain-containing proteins (including the p85 adaptor of PI3K and PLC- $\gamma$ ), leading to the inhibition of TCR-mediated NFAT/AP-1/NF-kB activation (Fig. 2) [114, 122, 134]. Conversely, transient TIM-3 expression was reported to increase TCR signalling, even after deleting most of its ectodomain [122]. In the absence of extracellular ligands, the molecular adaptor Bat3 binds to the TIM-3 intracellular tail, preventing TIM-3-mediated cell death or exhaustion of T cells. Ligand binding (such as gal-9 and Ceacam-1) results in the phosphorylation of 265 and 272 tyrosine residues, and in the release of Bat3, thus promoting TIM-3-mediated inhibitory functions. This allows the binding of $\mathrm{SH} 2$ domain-containing proteins and subsequent regulation of TCR signalling. Since Fyn and Bat 3 compete for the binding to the TIM-3 cytoplasmic tail, the molecular switch between TIM-3/Bat3 and TIM-3/Fyn complexes might 
be a major event in determining whether TIM-3 positively or negatively regulate TCR activation based on the features of the specific TME (Fig. 2) [131, 132, 135]. Remarkably, even though Ceacam-1 and gal- 9 bind to two different sites on the TIM-3 extracellular domain, their interaction with the receptor mediates similar downstream intracellular events, suggesting that the two signalling pathways could have synergistic effects on TIM-3 function [114].

\section{Targeting TIM-3 for Cancer Immunotherapy}

As mentioned above, despite some controversies, there is a general agreement in considering TIM- 3 to be a negative regulator of antitumour responses by modulating $\mathrm{CD}^{+} \mathrm{T}$-cell exhaustion and the Th1 response. In different tumours (e.g., melanoma, NSCLC, hepatocellular carcinoma, and cervical cancer), TIM-3 expression is upregulated in $\mathrm{CD}^{+}$and $\mathrm{CD} 8^{+}$TILs [136-143], and its expression associates with exhaustion of CD8+ T cells in metastatic melanoma and NSCLC $[115,144-145]$. Interestingly, TIM-3 upregulation is usually associated with that of PD-1 and TIM-3+/PD-1+ double-positive TILs exhibit the most severe exhausted phenotype, with marked inhibition of T-cell proliferation and reduction in IL-2, TNF, and IFN- $\gamma$ release $[114,116]$. This evidence provides a rationale for the co-administration of antiPD-1 and anti-TIM-3 mAbs to achieve a more effective control of tumour growth $[114,116]$. A consistent amount of TIM- $3^{+} / \mathrm{CD}^{+}$TILs expresses FoxP3 in a variety of tumours (e.g., hepatocellular, cervical, colorectal, and ovarian cancers), suggesting a role for TIM-3 in the regulation of Treg functions in TME $[138,146]$. In NSCLC, the presence of TIM- $3^{+}$Tregs correlates with unfavourable clinical-pathological parameters [145]. Additionally, tumour-derived TIM- $3^{+} /$FoxP $^{+}$Treg populations reveal a more suppressive capacity compared to $\mathrm{TIM}^{-} 3^{-} / \mathrm{FoxP}^{+}$cells, inhibiting $\mathrm{CD} 8^{+}$TIL proliferation and favouring T-cell exhaustion. Accordingly, depletion of TIM- $3^{+}$Tregs is associated with an increase in $\mathrm{CD}^{+} \mathrm{T}$ cells that no longer exhibit an exhausted phenotype $[138,145,146]$. TIM- $3^{+}$Tregs also co-express high levels of PD-1, supporting a functional relationship between PD-1 and the TIM-3 pathway in T cells with an exhausted phenotype $[114,132,138,145]$. Accumulating evidence also reveals that tumour cells themselves can express TIM-3 and this phenotype correlates with a poor prognosis [136, 147-153]. However, even though TIM-3 expression on the tumour cell surface seems to mediate immune escape through different mechanisms, ranging from the promotion of tumour cell migration to inhibi- tion of $\mathrm{CD} 4^{+}$functionality $[149,150,153]$, the molecular basis of TIM-3-mediated tumour/immune cell cross-talk is far from being completely understood.

Overall, the above-mentioned studies support the rationale for combining agents targeting TIM-3 with anti PD-1 mAbs [116]. In particular, in murine models, a TIM-3 and PD-1 dual blockade has been reported to overcome resistance to PD-1 monotherapy [154]. In this context, phase I clinical trials are evaluating the safety profile of anti-TIM-3 mAbs (i.e., Sym023; TSR-022; INCAGN02390; LY332I367; MBG453; BGBA425), alone or in combination with anti-PD-1 mAbs, targeted agents or chemotherapy, and of anti-TIM-3/ PD-L1 and anti-TIM-3/PD-1 bispecific antibodies (i.e., LY3415244 and RO7121661, respectively) for the treatment of different solid tumours (Table 2; www.clinicaltrials.gov).

\section{TIGIT}

Structural Characteristics and Signal Transduction of TIGIT

TIGIT (T-cell immunoreceptor with immunoglobulin and ITIM domains) is a member of the poliovirus receptor (PVR)-nectin family that inhibits T and NK cell activity and whose expression is tightly restricted to lymphocytes [155-157]. The high expression in many cells involved in cancer immunosurveillance (Tregs, $\mathrm{CD} 4^{+}$, $\mathrm{CD}^{+}$, and NK cells) makes TIGIT a promising target for cancer immunotherapy [156, 158-162]. Importantly, TIGIT expression defines Foxp $3^{+}$Tregs, whereas in CD $8^{+}$ lymphocytes it marks dysfunctional cells that co-express LAG-3, TIM-3, and PD-1 (see below) [157]. The TIGIT receptor is composed of: (i) an extracellular $\operatorname{IgV}$ domain, (ii) a transmembrane region, and (iii) a cytoplasmic tail that contains classical inhibitory motifs, ITIM, and ITT (unlike TIM-3 and LAG-3) [155, 163] (Fig. 3). The two main TIGIT ligands, CD155 (PVR) and CD112 (PVRL2), which are expressed on APC membranes, $\mathrm{T}$ and tumour cells [164-166], also bind to immune-activating receptor CD226 (DNAM-1). Contrary to TIGIT, CD226 enhances cytotoxicity of $\mathrm{T}$ lymphocytes and NK cells toward tumour cells [157]. The CD155-CD112/CD226/TIGIT axis shares molecular similarities with the B7/CD28/CTLA-4 pathway. In fact, TIGIT (like CTLA-4) binds to its ligands with higher affinity than CD226 and transmits an inhibitory downstream intracellular signalling that dampens the positive signal triggered by the CD155-CD112/CD226 interaction $[162,165]$. In NK cells, where TIGIT signal-
72

Chemotherapy 2019;64:62-80 DOI: $10.1159 / 000500902$
Tundo/Sbardella/Lacal/Graziani/Marini 
ling has been extensively studied, receptor activation induces a marked reduction of IFN- $\gamma$ release along with a significant decrease in cytotoxic activity [165, 167-169]. TIGIT/ligand interaction induces the phosphorylation of tyrosine residues in the ITT (Y225) and ITIM (Y231) cytoplasmic domains by Fyn and Lck kinases, and recruitment of phosphatase SHIP1 and SHIP 2 (through the adapter Grb2 and $\beta$-arrestin 2). This event prevents the activation of PI3K and NF-kB cascades, inhibiting NK effector function (Fig. 3) [162, 165, 167-169].

\section{TIGIT Role in Immune Biology of Cancer}

Apart from the well-characterized role in mediating NK function, in the context of TME, TIGIT/CD155 interaction also modulates the activity of DCs by stimulating the secretion of IL-10 and inhibiting that of IL-12, concurring in the acquisition of a tolerogenic phenotype [155]. These phenomena bring about the inhibition of IFN- $\gamma$ release and T-cell proliferation $[155,166]$. Therefore, TIGIT switches off the activity of key immune cells through a modification of the cytokine balance [160]. TIGIT is expressed in Foxp $3^{+}$Tregs, and it is fundamental in the maturation process of naïve $\mathrm{T}$ cells toward a Treg phenotype $[157,161]$. In fact, TIGIT+ Tregs display higher immunosuppressive properties compared to TIGIT $^{-}$Tregs [161, 170, 171]. Importantly, $\mathrm{TIGIT}^{+} / \mathrm{Foxp}^{+}$cells suppress pro-inflammatory Th1 and Th17 responses, but spare Th2 response through a fibrinogen-like 2-dependent mechanism and shift the cytokine production toward IL-10 [161, 172]. However, the role of the TIGIT pathway in mediating Treg response in the regulation of tumour growth is unclear, even though in murine models, TIGIT seems to play a greater role on Tregs than on $\mathrm{CD}^{+} \mathrm{T}$ cells in dampening the antitumour immune response [171]. Indeed, it has been proposed that TIGIT $^{+}$Tregs are involved in the initial phase of tumour development, but, once the tumour is grown, TIGIT appears to be more relevant in the regulation of $\mathrm{CD}^{+}$response $[162,171]$. In this context, it is worth mentioning that TIGIT is expressed at high levels on TILs in a broad range of tumours, and that, in the TME, TIGIT expression correlates with a marked $\mathrm{CD}^{+}$dysfunctional phenotype $[156,166,171,173]$. In fact, the TIGIT pathway directly inhibits T-cell activation and effector functions in a cell-specific manner by targeting TCR signalling (independently of APC-mediated mechanisms), which leads to a reduced secretion of pro-inflammatory cytokines and a reduced degranulation, supported by an increase in the secretion of the immunosuppressive cytokine IL-10 [159, 161].

Immune Checkpoint Inhibitors Targeting Lag-3, TIM-3, and TIGIT

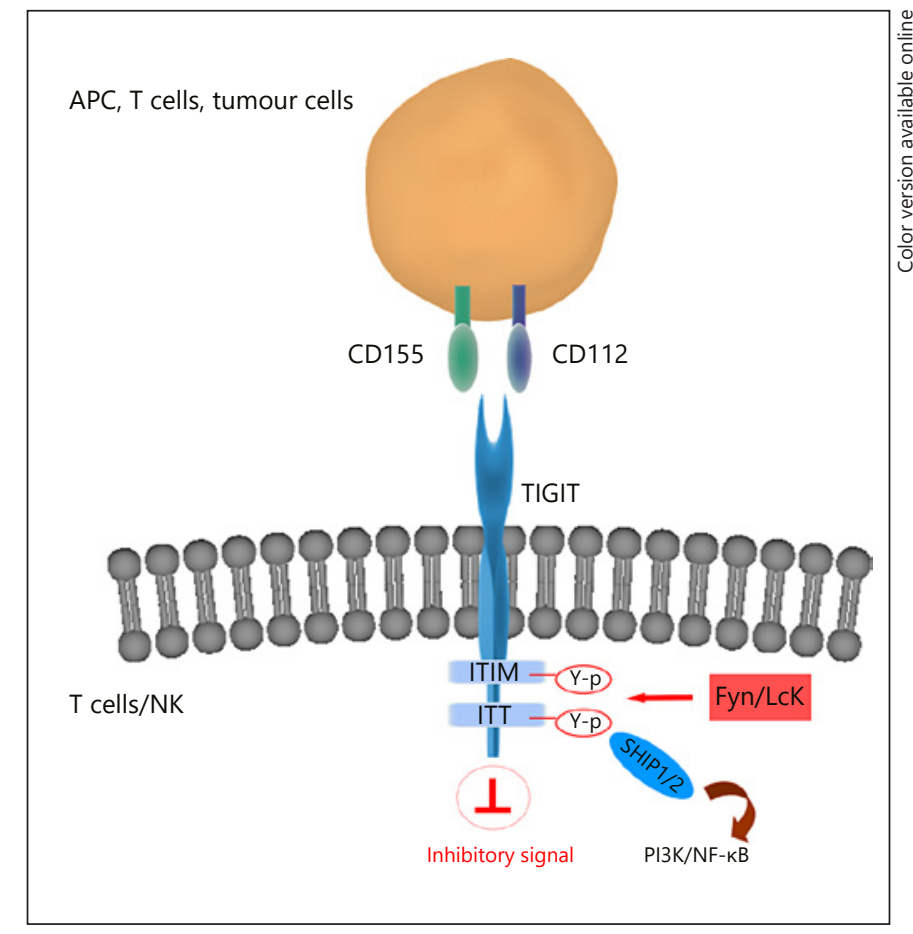

Fig. 3. TIGIT signalling in TME. TIGIT expression is restricted to lymphocytes. It binds two main ligands, CD155 and CD112, expressed in APC and tumour cells, and contains two classical inhibitory motives, ITIM and ITT in the cytoplasmic tail. Ligand/ TIGIT interaction induces the phosphorylation of tyrosine residues in the ITT and ITIM regions by Fyn and Lck kinases, and the recruitment of SHIP1 and SHIP2 proteins. This event leads to NK and T-cell suppression (see text for further details).

\section{Targeting TIGIT in Cancer Immunotherapy}

As discussed above, TIGIT modulates antitumour response in multiple steps, since it is involved in the inhibition of NK effector functions, suppression of DC costimulatory properties, modulation of Treg response, and the inhibition of $\mathrm{CD}^{+}$cytotoxicity [162]. Importantly, $\mathrm{CD} 8^{+}$ TILs with the most exhausted phenotype co-express PD-1, TIM-3, and TIGIT [156, 166, 171, 173, 174], thus the simultaneous blockade of PD-1/PD-L1 (and/or TIM3) and TIGIT might be a useful strategy to restore the functionality of CD8 ${ }^{+}$TILs $[156,166,173]$. Indeed, administration of mAbs against TIGIT and PD-1 in the CT26 murine colon carcinoma model induced tumour rejection and reverted $\mathrm{CD}^{+}$exhaustion [156]. Accordingly, in CD8 ${ }^{+}$TILs from melanoma patients, a combined blockade of TIGIT and PD-1 increased proliferation, cytokine production, and degranulation process [173]. Moreover, TIGIT knockdown restored cytokine production in $\mathrm{CD} 8^{+}$TILs from acute myeloid leukaemia patients

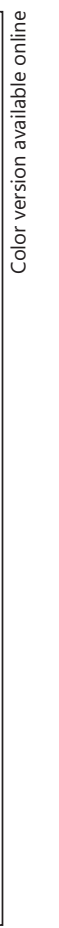


[175]. An intriguing open question concerning the synergistic co-blockade of TIGIT and of PD-1/PD-L1 axes regards whether or not immunostimulation mainly derives from the functional restoration of exhausted $\mathrm{T}$ cells within the tumour and/or from an increase of $\mathrm{CD} 8^{+}$cell recruitment from the lymph nodes to the tumour site $[156,162,176,177]$. Consistently with these findings, a number of phase I clinical trials with mAbs directed toward TIGIT, alone or in combination with anti PD-1 or PD-L1 mAbs, are currently ongoing in patients with solid tumours (Table 2; www.clinicaltrials.gov).

\section{Conclusion}

The successful application of the anti-CTLA-4 and anti-PD-1/PD-L1 mAbs has paved the way to a new era of anticancer therapy changing the therapeutic scenario in a number of tumour settings. However, clinical benefit is still limited to a subset of patients, which is likely due to the heterogeneity of the cancer immunogenic profile during growth and dissemination, and acquisition of resistance mechanisms. In fact, TME undergoes continuous remodelling during tumour progression and TME features vary in primary and metastatic sites. Therefore, a major challenge is to assess the precise molecular features of a given TME and the dynamic interplay between immune and cancer cells in the context of TME. However, with the exception of PD-L1 for certain tumour types, in most cases reliable tumour- or TME-associated biomarkers to stratify patients into responder and non-responder categories are not yet available. The clinical experience accumulated to date with the co-administration of nivolumab and ipilimumab has strengthened the evidence that the combination of drugs targeting different ICK regulatory pathways is a feasible approach to improve treatment efficacy and potentially delay or prevent tumour resistance. Moreover, in order to further increase the proportion of patients that might obtain durable responses, a better understanding of the immune regulatory networks of stimulatory and inhibitory pathways in the context of TME is mandatory.

Over the last decade, the landscape of inhibitory pathways has expanded to include LAG-3, TIM-3, and TIGIT, which display functional redundancy with CTLA-4 and PD-1/PD-L1 axes, but also unique molecular signalling associated with specific regulatory roles. A recently proposed model $[44,166]$ envisages that immune surveillance fulfilment is guaranteed by the hierarchical organization of co-inhibitory pathways, in which CTLA-4 and
PD-1/PD-L1 axes dominate the scenario, whereas LAG3, TIM-3, and TIGIT represent the second line of action. However, some aspects of functional redundancy of these different pathways suggest that they might co-operate to maintain immune homeostasis. Therefore, it is possible that the "spatial" and "temporal" differences of the first(CTLA-4 and PD-1/PD-L1) and the second-line (LAG-3, TIM-3, TIGIT) pathways are not so marked. Therapies targeting LAG-3, TIM-3, and TIGIT, either as monotherapy or in combination with other ICKi, are undergoing clinical development. In this regard, a comprehensive understanding of the role played by these (and other) "new generation" ICKs in the immune response against different cancer types might offer unprecedented therapeutic opportunities, particularly in the context of combinatorial strategies with "first-generation" immunotherapies and/or other targeted agents.

\section{Appendix}

The cytotoxic T-lymphocyte antigen 4 (CTLA-4) acts as a negative regulator of the co-stimulatory signal that is required for $\mathrm{T}$ cell activation $[2,47,178]$. According to the double-signal model, two simultaneous events are required for primary T-cell activation. The first signal is represented by the binding of TCR to an MHC molecule of an activated APC loaded with a specific peptide antigen; the second one is provided by the interaction of the T-cell co-stimulatory receptor CD28 with its ligands, B7-1 (CD80) and (CD86) B7-2, expressed on the surface of APC. In resting naïve T cells, CTLA-4, which is a CD28 homolog with much higher affinity for B7, localizes primarily in the intracellular compartment [178, 179]. Stimulatory signals resulting from both TCR/MHC and CD28/B7 binding induce exocytosis of CTLA-4 from CTLA4-containing vesicles, and its translocation to the T-cell surface. Here, CTLA-4 outcompetes CD28 in its binding to B7-1 and B7-2. Maximal CTLA-4 expression on the T-cell surface is reached within 2-3 days from the stimulatory signal, allowing the immune system to be operative in the first phase and to be blocked when the threat is likely defeated $[1,178-180]$. In fact, CTLA4/B7 transmits an inhibitory signal to $\mathrm{T}$ cells that downregulates IL-2 production, and reduces the proliferation rate and survival of activated $\mathrm{T}$ cells [179-181]. The relative amount of the CD28/B7 complex versus the CTLA-4/B7 one determines whether a T cell will undergo activation or anergy (i.e., T-cell non-responsiveness in response to an antigen). Blockade of CTLA-4 in T-lymphocytes hampers the inhibitory signal that derives from its binding to B7 expressed on APC membranes [179-181]. Therefore, anti-CTLA-4 antibodies favour the reactivation of $\mathrm{T}$ lymphocytes during the phase of antigen presentation by APCs, stimulating a more robust antitumour response $[1,2,178]$.

Whilst CTLA-4 is operative during the priming phase of T-cell activation, the programmed death (PD-1) pathway (a member of the CD28 family of receptors) acts during the effector phase, dampening cell activation predominantly within peripheral tissues $[47,182]$. The expression of PD-1 is transcriptionally induced 
upon T-cell activation, whereas it is absent on naïve T cells. PD-1 regulates $\mathrm{T}$-cell activation through the binding to its ligands, $\mathrm{PD}$ L1 and PD-L2. Even though CTLA-4 and PD-1 seem to cover similar inhibitory effects on T-cell activity (e.g., inhibition of T-cell proliferation and survival, reduction in IL-2 and IFN- $\gamma$ release), these pathways differ in their timing and tissue localization [47, 182]. Remarkably, PD-1 expression (together with other ICK) is a hallmark of "exhausted" T cells (see throughout the text), a condition characterized by T-cell dysfunction occurring during chronic infections and cancer, which results in a suboptimal control of these threats [183-185]. PD-L1 and PD-L2 are widely expressed in healthy cells (PD-L1 is primarily expressed by leukocytes, hematopoietic cells, and non-lymphoid tissues, whereas PD-L2 is detected in DCs and monocytes) and, especially PD-L1, in a wide variety of tumour cells. After PD-L1 or PD-L2 engagement, PD-1 primarily transmits a negative co-stimulatory signal in order to limit T-cell activation through the recruitment of the tyrosine phosphatase SHP2, which attenuates TCR signalling [183]. Remarkably, SHP2 leads to preferential de-phosphorylation of CD28 rather than TCR. This phenomenon, along with the CTLA-4 inhibition of CD28 signalling discussed above, might represent a functional convergence point between CTLA-4 and PD-1 along the CD28 pathway [182]. Blockade of PD-1 signalling prevents $\mathrm{PD}$ 1-mediated attenuation of TCR signalling and allows the reactivation of exhausted $\mathrm{CD}^{+}$effectors. Therefore, despite continued PD-L1 ligand expression within TME, exhausted T cells are able to mount an effective immune response towards tumour cells [182185]. Since CTLA-4 inhibition hampers the induction phase of antitumour T-cell immunity in lymphoid tissues, whereas PD-1 inhibition primarily affects the effector phase within the TME, the dual blockade of both ICKs results in additive/synergistic effects $[1,2,186]$.

\section{Statement of Ethics}

The authors have no ethical conflicts to disclose.

\section{Disclosure Statement}

The authors have no conflicts of interest to declare.

\section{Funding Sources}

This work was supported by the Italian Association for Cancer Research (AIRC) Investigator Grant IG No. 20,353 to G.G. and by RC2019/2750061 from the Italian Ministry of Health to P.M.L.

\section{Author Contributions}

Conceptualization: G.R.T., D.S., and G.G.; writing of original draft preparation: G.R.T., D.S., G.G.; critical review of the manuscript: P.M.L.; review and editing, G.G. and S.M.

\section{References}

1 Wei SC, Duffy CR, Allison JP. Mechanisms of immune checkpoint blockade therapy. Cancer Discov. 2018 Sep;8(9):1069-86.

2 Krummel MF, Allison JP. CD28 and CTLA-4 have opposing effects on the response of $\mathrm{T}$ cells to stimulation. J Exp Med. 1995 Aug; 182(2):459-65.

3 Graziani G, Tentori L, Navarra P. Ipilimumab: a novel immunostimulatory monoclonal antibody for the treatment of cancer. Pharmacol Res. 2012 Jan;65(1):9-22.

4 Tentori L, Lacal PM, Graziani G. Challenging resistance mechanisms to therapies for metastatic melanoma. Trends Pharmacol Sci. 2013 Dec;34(12):656-66.

5 Hodi FS, O’Day SJ, McDermott DF, Weber RW, Sosman JA, Haanen JB, et al. Improved survival with ipilimumab in patients with metastatic melanoma. N Engl J Med. 2010 Aug;363(8):711-23.

6 Robert C, Thomas L, Bondarenko I, O’Day S, Weber J, Garbe C, et al. Ipilimumab plus dacarbazine for previously untreated metastatic melanoma. N Engl J Med. 2011 Jun;364(26): 2517-26.

Immune Checkpoint Inhibitors Targeting Lag-3, TIM-3, and TIGIT
7 Garbe C, Eigentler TK, Keilholz U, Hauschild A, Kirkwood JM. Systematic review of medical treatment in melanoma: current status and future prospects. Oncologist. 2011;16(1):524.

8 Schadendorf D, Hodi FS, Robert C, Weber JS, Margolin K, Hamid O, et al. Pooled Analysis of Long-Term Survival Data From Phase II and Phase III Trials of Ipilimumab in Unresectable or Metastatic Melanoma. J Clin Oncol. 2015 Jun;33(17):1889-94.

9 Kim C, Lee CW, Kovacic L, Shah A, Klasa R, Savage KJ. Long-term survival in patients with metastatic melanoma treated with DTIC or temozolomide. Oncologist. 2010;15(7): 765-71.

10 Calpe-Armero P, Ferriols-Lisart R, FerriolsLisart F, Pérez-Pitarch A. Effectiveness of Nivolumab versus Docetaxel as Second-Line Treatment in Non-Small Cell Lung Cancer Patients in Clinical Practice. Chemotherapy. 2017;62(6):374-80.

11 Constantinidou A, Alifieris C, Trafalis DT. Targeting programmed cell death-1 (PD-1) and ligand (PD-L1): a new era in cancer active immunotherapy. Pharmacol Ther. 2019;194: 84-106.
12 Poma MJ, Ostios Garcia L, Villamayor Sanchez J, D'errico G. What do we know about cancer immunotherapy? Long-term survival and immune-related adverse events. Allergol Immunopathol. 2019;47(3):303-8.

13 Topalian SL, Drake CG, Pardoll DM. Immune checkpoint blockade: a common denominator approach to cancer therapy. Cancer Cell. 2015 Apr;27(4):450-61.

14 Larkin J, Chiarion-Sileni V, Gonzalez R, Grob JJ, Cowey CL, Lao CD, et al. Combined nivolumab and ipilimumab or monotherapy in untreated melanoma. N Engl J Med. 2015 Jul;373(1):23-34.

15 Postow MA, Chesney J, Pavlick AC, Robert C, Grossmann K, McDermott D, et al. Nivolum$\mathrm{ab}$ and ipilimumab versus ipilimumab in untreated melanoma. N Engl J Med. 2015 May; 372(21):2006-17.

16 Robert C, Schachter J, Long GV, Arance A, Grob JJ, Mortier L, et al.; KEYNOTE-006 investigators. Pembrolizumab versus Ipilimumab in Advanced Melanoma. N Engl J Med. 2015 Jun;372(26):2521-32. 
17 Schachter J, Ribas A, Long GV, Arance A, Grob JJ, Mortier L, et al. Pembrolizumab versus ipilimumab for advanced melanoma: final overall survival results of a multicentre, randomised, open-label phase 3 study (KEYNOTE-006). Lancet. 2017 Oct;390(10105): 1853-62.

18 Korman A, Chen B, Wang C, Wu L, Cardarelli P, Selby M. Activity of anti-PD-1 in murine tumour models: role of "host" PD-L1 and synergistic effect of anti-PD-1 and anti-CTLA-4. J Immunol. 2007;178:1-48.

19 Wolchok JD, Chiarion-Sileni V, Gonzalez R, Rutkowski P, Grob JJ, Cowey CL, et al. Overall Survival with Combined Nivolumab and Ipilimumab in Advanced Melanoma. N Engl J Med. 2017 Oct;377(14):1345-56.

20 Hodi FS, Chiarion-Sileni V, Gonzalez R, Grob JJ, Rutkowski P, Cowey CL, et al. Nivolumab plus ipilimumab or nivolumab alone versus ipilimumab alone in advanced melanoma (CheckMate 067): 4-year outcomes of a multicentre, randomised, phase 3 trial. Lancet Oncol. 2018 Nov;19(11):1480-92.

21 Topalian SL, Sznol M, McDermott DF, Kluger HM, Carvajal RD, Sharfman WH, et al. Survival, durable tumor remission, and longterm safety in patients with advanced melanoma receiving nivolumab. J Clin Oncol. 2014 Apr;32(10):1020-30.

22 Sharma P, Allison JP. The future of immune checkpoint therapy. Science. 2015 Apr; 348(6230):56-61.

23 Spranger S. Mechanisms of tumor escape in the context of the T-cell-inflamed and the non-T-cell-inflamed tumor microenvironment. Int Immunol. 2016 Aug;28(8):383-91.

24 Gettinger S, Horn L, Jackman D, Spigel D, Antonia S, Hellmann M, et al. Five-Year Follow-Up of nivolumab in previously treated advanced Non-Small-Cell Lung cancer: Results From the CA209-003 Study. J Clin Oncol. 2018 Jun;36(17):1675-84.

25 Kotake M, Miura Y, Imai H, Mori K, Sakurai R, Kaira K, et al. Post-Progression Survival Associated with Overall Survival in Patients with Advanced Non-Small-Cell Lung Cancer Receiving Docetaxel Monotherapy as Second-Line Chemotherapy. Chemotherapy. 2017;62(4):205-13.

26 Battaglin F, Naseem M, Lenz HJ, Salem ME. Microsatellite instability in colorectal cancer: overview of its clinical significance and novel perspectives. Clin Adv Hematol Oncol. 2018 Nov;16(11):735-45.

27 Motzer RJ, Tannir NM, McDermott DF, Arén Frontera O, Melichar B, Choueiri TK, et al.; CheckMate 214 Investigators. Nivolumab plus ipilimumab versus sunitinib in advanced renal-cell carcinoma. N Engl J Med. 2018 Apr; 378(14):1277-90.

28 Murata S, Takahama Y, Kasahara M, Tanaka $\mathrm{K}$. The immunoproteasome and thymoproteasome: functions, evolution and human disease. Nat Immunol. 2018 Sep;19(9):923-31.
29 Overman MJ, Lonardi S, Wong KY, Lenz HJ, Gelsomino F, Aglietta M, et al. Durable clinical benefit with nivolumab plus ipilimumab in DNA Mismatch Repair-Deficient/Microsatellite Instability-High metastatic colorectal cancer. J Clin Oncol. 2018 Mar;36(8):773-9.

30 Gioia M, Monaco S, Van Den Steen PE, Sbardella D, Grasso G, Marini S, et al. The collagen binding domain of gelatinase A modulates degradation of collagen IV by gelatinase B. J Mol Biol. 2009 Feb;386(2):419-34.

31 Bergers G, Brekken R, McMahon G, Vu TH, Itoh T, Tamaki K, et al. Matrix metalloproteinase- 9 triggers the angiogenic switch during carcinogenesis. Nat Cell Biol. 2000 Oct; 2(10):737-44

32 Kessenbrock K, Plaks V, Werb Z. Matrix metalloproteinases: regulators of the tumor microenvironment. Cell. 2010 Apr;141(1):5267.

33 Sbardella D, Inzitari R, Iavarone F, Gioia M, Marini S, Sciandra F, et al. Enzymatic processing by MMP-2 and MMP-9 of wild-type and mutated mouse $\beta$-dystroglycan. IUBMB Life. 2012 Dec;64(12):988-94.

34 Lamouille S, Xu J, Derynck R. Molecular mechanisms of epithelial-mesenchymal transition. Nat Rev Mol Cell Biol. 2014 Mar;15(3): 178-96.

35 Sbardella D, Fasciglione GF, Gioia M, Ciaccio C, Tundo GR, Marini S, et al. Human matrix metalloproteinases: an ubiquitarian class of enzymes involved in several pathological processes. Mol Aspects Med. 2012 Apr;33(2): 119-208.

36 Rivera LB, Meyronet D, Hervieu V, Frederick MJ, Bergsland E, Bergers G. Intratumoral myeloid cells regulate responsiveness and resistance to antiangiogenic therapy. Cell Rep. 2015 Apr;11(4):577-91.

37 Tartour E, Pere H, Maillere B, Terme M, Merillon N, Taieb J, et al. Angiogenesis and immunity: a bidirectional link potentially relevant for the monitoring of antiangiogenic therapy and the development of novel therapeutic combination with immunotherapy. Cancer Metastasis Rev. 2011 Mar;30(1):8395.

38 Eissler N, Mao Y, Brodin D, Reuterswärd P, Andersson Svahn H, Johnsen JI, et al. Regulation of myeloid cells by activated T cells determines the efficacy of PD-1 blockade. OncoImmunology. 2016 Sep;5(12):e1232222.

39 Graziani G, Ruffini F, Tentori L, Scimeca M, Dorio AS, Atzori MG, et al. Antitumor activity of a novel anti-vascular endothelial growth factor receptor-1 monoclonal antibody that does not interfere with ligand binding. Oncotarget. 2016 Nov; 7(45):72868-85.

40 Atzori MG, Tentori L, Ruffini F, Ceci C, Bonanno E, Scimeca M, et al. The anti-vascular endothelial growth factor receptor-1 monoclonal antibody D16f7 inhibits glioma growth and angiogenesis in vivo. J Pharmacol Exp Ther. 2018 Jan;364(1):77-86.
41 Lacal PM, Atzori MG, Ruffini F, Tentori L, Graziani G. Poly(ADP-ribose) polymerase inhibitor olaparib hampers placental growth factor-driven activation of myelomonocytic cells. Oncol Rep. 2018 May;39(5):2261-9.

42 Lacal PM, Graziani G. Therapeutic implication of vascular endothelial growth factor receptor-1 (VEGFR-1) targeting in cancer cells and tumor microenvironment by competitive and non-competitive inhibitors. Pharmacol Res. 2018 Oct;136:97-107.

43 Duan J, Wang Y, Jiao S. Checkpoint blockadebased immunotherapy in the context of tumor microenvironment: opportunities and challenges. Cancer Med. 2018 Sep;7(9):4517-29.

44 Marin-Acevedo JA, Dholaria B, Soyano AE, Knutson KL, Chumsri S, Lou Y. Next generation of immune checkpoint therapy in cancer: new developments and challenges. J Hematol Oncol. 2018 Mar;11(1):39.

45 Salama AK, Moschos SJ. Next steps in immuno-oncology: enhancing antitumor effects through appropriate patient selection and rationally designed combination strategies. Ann Oncol. 2017 Jan;28(1):57-74.

46 Karamouzis MV, Papavassiliou AG. Combination of checkpoint inhibitors with other agents as a strategy to improve anti-cancer effect - a glimpse to the future. Expert Opin Investig Drugs. 2018 Jul;27(7):569-72.

47 Zahavi DJ, Weiner LM: Targeting multiple receptors to increase checkpoint blockade efficacy. Int J Mol Sci. 2019; 4:20(1):158. https:// doi.org/10.3390/ijms20010158.

48 Amatore F, Gorvel L, Olive D. Inducible CoStimulator (ICOS) as a potential therapeutic target for anti-cancer therapy. Expert Opin Ther Targets. 2018 Apr;22(4):343-51.

49 Beatty GL, Li Y, Long KB. Cancer immunotherapy: activating innate and adaptive immunity through CD40 agonists. Expert Rev Anticancer Ther. 2017 Feb;17(2):175-86.

50 Riccardi C, Ronchetti S, Nocentini G. Glucocorticoid-induced TNFR-related gene (GITR) as a therapeutic target for immunotherapy. Expert Opin Ther Targets. 2018 Sep;22(9): 783-97.

51 Sasidharan Nair V, Elkord E. Immune checkpoint inhibitors in cancer therapy: a focus on T-regulatory cells. Immunol Cell Biol. 2018 Jan;96(1):21-33.

52 Waight JD, Gombos RB, Wilson NS. Harnessing co-stimulatory TNF receptors for cancer immunotherapy: current approaches and future opportunities. Hum Antibodies. 2017; 25(3-4):87-109.

53 Chester C, Sanmamed MF, Wang J, Melero I. Immunotherapy targeting 4-1BB: mechanistic rationale, clinical results, and future strategies. Blood. 2018 Jan;131(1):49-57.

54 Lam ET, Eckhardt SG, Messersmith W, Jimeno A, O'Bryant CL, Ramanathan RK, et al. Phase I Study of Enavatuzumab, a First-inClass Humanized Monoclonal Antibody Targeting the TWEAK Receptor, in Patients with Advanced Solid Tumors. Mol Cancer Ther. 2018 Jan;17(1):215-21. 
55 Huard B, Gaulard P, Faure F, Hercend T, Triebel F. Cellular expression and tissue distribution of the human LAG-3-encoded protein, an MHC class II ligand. Immunogenetics. 1994;39(3):213-7.

56 Huard B, Tournier M, Triebel F. LAG-3 does not define a specific mode of natural killing in human. Immunol Lett. 1998 Apr;61(2-3): 109-12.

57 Kisielow M, Kisielow J, Capoferri-Sollami G, Karjalainen K. Expression of lymphocyte activation gene 3 (LAG-3) on B cells is induced by $\mathrm{T}$ cells. Eur J Immunol. $2005 \mathrm{Jul}$;35(7): 2081-8.

58 Andreae S, Buisson S, Triebel F. MHC class II signal transduction in human dendritic cells induced by a natural ligand, the LAG-3 protein (CD223). Blood. 2003 Sep;102(6):21307.

59 Huang CT, Workman CJ, Flies D, Pan X, Marson AL, Zhou G, et al. Role of LAG-3 in regulatory T cells. Immunity. 2004 Oct;21(4): 503-13.

60 Durham NM, Nirschl CJ, Jackson CM, Elias J, Kochel CM, Anders RA, et al. Lymphocyte Activation Gene 3 (LAG-3) modulates the ability of CD4 T-cells to be suppressed in vivo. PLoS One. 2014 Nov;9(11):e109080.

61 Peña J, Jones NG, Bousheri S, Bangsberg DR, Cao H. Lymphocyte activation gene-3 expression defines a discrete subset of HIV-specific CD8+ T cells that is associated with lower viral load. AIDS Res Hum Retroviruses. 2014 Jun;30(6):535-41.

62 Dijkstra JM, Somamoto T, Moore L, Hordvik I, Ototake M, Fischer U. Identification and characterization of a second CD4-like gene in teleost fish. Mol Immunol. 2006 Feb;43(5): 410-9.

63 Huard B, Prigent P, Tournier M, Bruniquel D, Triebel F. CD4/major histocompatibility complex class II interaction analyzed with CD4- and lymphocyte activation gene-3 (LAG-3)-Ig fusion proteins. Eur J Immunol. 1995 Sep;25(9):2718-21.

64 Goldberg MV, Drake CG. LAG-3 in cancer immunotherapy. Curr Top Microbiol Immunol. 2011;344:269-78.

65 Fleury S, Lamarre D, Meloche S, Ryu SE, Cantin C, Hendrickson WA, et al. Mutational analysis of the interaction between CD4 and class II MHC: class II antigens contact CD4 on a surface opposite the gp120-binding site. Cell. 1991 Sep;66(5):1037-49.

66 Andrews LP, Marciscano AE, Drake CG, Vignali DA. LAG3 (CD223) as a cancer immunotherapy target. Immunol Rev. 2017 Mar; 276(1):80-96.

67 Workman CJ, Dugger KJ, Vignali DA. Cutting edge: molecular analysis of the negative regulatory function of lymphocyte activation gene-3. J Immunol. 2002 Nov; 169(10):53925 .

68 Maçon-Lemaître L, Triebel F. The negative regulatory function of the lymphocyte-activation gene-3 co-receptor (CD223) on human T cells. Immunology. 2005 Jun;115(2):170-8.
69 Long L, Zhang X, Chen F, Pan Q, Phiphatwatchara $\mathrm{P}$, Zeng $\mathrm{Y}$, et al. The promising immune checkpoint LAG-3: from tumor microenvironment to cancer immunotherapy. Genes Cancer. 2018 May;9(5-6):176-89.

70 Hannier S, Tournier M, Bismuth G, Triebel F. CD3/TCR complex-associated lymphocyte activation gene-3 molecules inhibit CD3/ TCR signaling. J Immunol. 1998 Oct;161(8): 4058-65.

71 Hannier S, Triebel F. The MHC class II ligand lymphocyte activation gene-3 is co-distributed with CD8 and CD3-TCR molecules after their engagement by $\mathrm{mAb}$ or peptide-MHC class I complexes. Int Immunol. 1999 Nov; 11(11):1745-52.

72 Workman CJ, Rice DS, Dugger KJ, Kurschner $\mathrm{C}$, Vignali DA. Phenotypic analysis of the murine CD4-related glycoprotein, CD223 (LAG3). Eur J Immunol. 2002 Aug;32(8):2255-63.

73 Workman CJ, Cauley LS, Kim IJ, Blackman MA, Woodland DL, Vignali DA. Lymphocyte activation gene-3 (CD223) regulates the size of the expanding $\mathrm{T}$ cell population following antigen activation in vivo. J Immunol. 2004 May; 172(9):5450-5.

74 Workman CJ, Vignali DA. The CD4-related molecule, LAG-3 (CD223), regulates the expansion of activated T cells. Eur J Immunol. 2003 Apr;33(4):970-9.

75 Scala E, Carbonari M, Del Porto P, Cibati M, Tedesco T, Mazzone AM, et al. Lymphocyte activation gene-3 (LAG-3) expression and IFNgamma production are variably coregulated in different human $\mathrm{T}$ lymphocyte subpopulations. J Immunol. 1998 Jul;161(1):489-93.

76 Matsuzaki J, Gnjatic S, Mhawech-Fauceglia P, Beck A, Miller A, Tsuji T, et al. Tumor-infiltrating NY-ESO-1-specific CD8+ T cells are negatively regulated by LAG-3 and PD-1 in human ovarian cancer. Proc Natl Acad Sci USA. 2010 Apr;107(17):7875-80.

77 Li FJ, Zhang Y, Jin GX, Yao L, Wu DQ. Expression of LAG-3 is coincident with the impaired effector function of $\mathrm{HBV}$-specific CD8(+) T cell in HCC patients. Immunol Lett. 2013 Feb;150(1-2):116-22.

78 Sittig SP, Køllgaard T, Grønbæk K, Idorn M, Hennenlotter J, Stenzl A, et al. Clonal expansion of renal cell carcinoma-infiltrating $\mathrm{T}$ lymphocytes. OncoImmunology. 2013 Sep; 2(9):e26014.

79 Mishra AK, Kadoishi T, Wang X, Driver E, Chen Z, Wang XJ, et al. Squamous cell carcinomas escape immune surveillance via inducing chronic activation and exhaustion of CD8+ T Cells co-expressing PD-1 and LAG-3 inhibitory receptors. Oncotarget. 2016 Dec; 7(49):81341-56.

80 Grosso JF, Kelleher CC, Harris TJ, Maris CH, Hipkiss EL, De Marzo A, et al. LAG-3 regulates CD8+ T cell accumulation and effector function in murine self- and tumor-tolerance systems. J Clin Invest. 2007 Nov;117(11): 3383-92.
81 Bos R, Marquardt KL, Cheung J, Sherman LA. Functional differences between low- and high-affinity CD8(+) T cells in the tumor environment. OncoImmunology. 2012 Nov; 1(8):1239-47.

82 Xu F, Liu J, Liu D, Liu B, Wang M, Hu Z, et al. LSECtin expressed on melanoma cells promotes tumor progression by inhibiting antitumor T-cell responses. Cancer Res. 2014 Jul; 74(13):3418-28.

83 Kouo T, Huang L, Pucsek AB, Cao M, Solt S, Armstrong T, et al. Galectin-3 shapes antitumor immune responses by suppressing $\mathrm{CD} 8+$ $\mathrm{T}$ cells via LAG-3 and inhibiting expansion of plasmacytoid dendritic cells. Cancer Immunol Res. 2015 Apr;3(4):412-23.

84 Farsam V, Hassan ZM, Zavaran-Hosseini A, Noori S, Mahdavi M, Ranjbar M. Antitumor and immunomodulatory properties of artemether and its ability to reduce CD4+ CD25+ FoxP3+ T reg cells in vivo. Int Immunopharmacol. 2011 Nov;11(11):1802-8.

85 Wei T, Zhang J, Qin Y, Wu Y, Zhu L, Lu L, et al. Increased expression of immunosuppressive molecules on intratumoral and circulating regulatory $\mathrm{T}$ cells in non-small-cell lung cancer patients. Am J Cancer Res. 2015 Jun; 5(7):2190-201.

86 Fallarino F, Grohmann U, Hwang KW, Orabona C, Vacca C, Bianchi R, et al. Modulation of tryptophan catabolism by regulatory $\mathrm{T}$ cells. Nat Immunol. 2003 Dec;4(12):1206-12.

87 Thornton AM, Shevach EM. CD4+CD25+ immunoregulatory $\mathrm{T}$ cells suppress polyclonal $\mathrm{T}$ cell activation in vitro by inhibiting interleukin 2 production. J Exp Med. 1998 Jul; 188(2):287-96.

88 Liang B, Workman C, Lee J, Chew C, Dale $\mathrm{BM}$, Colonna L, et al. Regulatory T cells inhibit dendritic cells by lymphocyte activation gene- 3 engagement of MHC class II. J Immunol. 2008 May;180(9):5916-26.

89 Workman CJ, Wang Y, El Kasmi KC, Pardoll DM, Murray PJ, Drake CG, et al. LAG-3 regulates plasmacytoid dendritic cell homeostasis. J Immunol. 2009 Feb;182(4):1885-91.

90 Nguyen LT, Ohashi PS. Clinical blockade of PD1 and LAG3 - potential mechanisms of action. Nat Rev Immunol. 2015 Jan;15(1):45-56.

91 Woo SR, Turnis ME, Goldberg MV, Bankoti J, Selby M, Nirschl CJ, et al. Immune inhibitory molecules LAG-3 and PD-1 synergistically regulate $\mathrm{T}$-cell function to promote tumoral immune escape. Cancer Res. $2012 \mathrm{Feb}$; 72(4):917-27.

92 Takaya S, Saito H, Ikeguchi M. Upregulation of immune checkpoint molecules, PD-1 and LAG-3, on CD4+ and CD8+ T cells after gastric cancer surgery. Yonago Acta Med. 2015 Mar;58(1):39-44.

$93 \mathrm{He} \mathrm{Y,} \mathrm{Yu} \mathrm{H,} \mathrm{Rozeboom} \mathrm{L,} \mathrm{Rivard} \mathrm{CJ,} \mathrm{Ellison}$ K, Dziadziuszko R, et al. LAG-3 Protein Expression in Non-Small Cell lung cancer and its relationship with PD-1/PD-L1 and tumorinfiltrating lymphocytes. J Thorac Oncol. 2017 May; 12(5):814-23. 
94 Yang ZZ, Kim HJ, Villasboas JC, Chen YP, Price-Troska T, Jalali S, et al. Expression of LAG-3 defines exhaustion of intratumoral PD- $1+\mathrm{T}$ cells and correlates with poor outcome in follicular lymphoma. Oncotarget. 2017 May;8(37):61425-39.

95 Wierz M, Pierson S, Guyonnet L, Viry E, Lequeux A, Oudin A, et al. Dual PD1/LAG3 immune checkpoint blockade limits tumor development in a murine model of chronic lymphocytic leukemia. Blood. 2018 Apr; 131(14):1617-21.

96 Huang RY, Francois A, McGray AR, Miliotto A, Odunsi K. Compensatory upregulation of PD-1, LAG-3, and CTLA-4 limits the efficacy of single-agent checkpoint blockade in metastatic ovarian cancer. OncoImmunology. 2016 Oct;6(1):e1249561.

97 Brignone C, Escudier B, Grygar C, Marcu M, Triebel F. A phase I pharmacokinetic and biological correlative study of IMP321, a novel MHC class II agonist, in patients with advanced renal cell carcinoma. Clin Cancer Res. 2009 Oct;15(19):6225-31.

98 Wang-Gillam A, Plambeck-Suess S, Goedegebuure P, Simon PO, Mitchem JB, Hornick JR, et al. A phase I study of IMP321 and gemcitabine as the front-line therapy in patients with advanced pancreatic adenocarcinoma. Invest New Drugs. 2013 Jun;31(3):707-13.

99 Romano E, Michielin O, Voelter V, Laurent J, Bichat $\mathrm{H}$, Stravodimou A, et al. MART-1 peptide vaccination plus IMP321 (LAG-3Ig fusion protein) in patients receiving autologous PBMCs after lymphodepletion: results of a Phase I trial. J Transl Med. 2014 Apr; 12(1):97.

100 Brignone C, Gutierrez M, Mefti F, Brain E, Jarcau R, Cvitkovic F, et al. First-line chemoimmunotherapy in metastatic breast carcinoma: combination of paclitaxel and IMP321 (LAG-3Ig) enhances immune responses and antitumor activity. J Transl Med. 2010 Jul;8(1):71.

101 Ascierto PA, Bono P, Bhatia S, Melero I, Nyakas MS, Svane I, et al. LBA18: efficacy of BMS-986016, a monoclonal antibody that targets lymphocyte activation gene-3 (LAG3 ), in combination with nivolumab in pts with melanoma who progressed during prior anti-PD-1/PD-L1 therapy (mel prior IO) in all-comer and biomarker-enriched populations. Ann Oncol. 2017;28(suppl 5): mdx440.011.

102 Ascierto PA, McArthur GA. Checkpoint inhibitors in melanoma and early phase development in solid tumors: what's the future? J Transl Med. 2017 Aug;15(1):173.

103 Lewis K, Hauschild A, Larkin J, Ribas A, Flaherty KT, McArthur GA, et al. Effect of concomitant dosing with acid-reducing agents and vemurafenib dose on survival in patients with BRAFV600 mutation-positive metastatic melanoma treated with vemurafenib \pm cobimetinib. Eur J Cancer. 2019; 116:45-55.
104 Ascierto PA, Melero I, Bhatia S, Bono P, Sanborn RE, Lipson EJ, et al. Initial efficacy of anti-lymphocyte activation gene-3 (antiLAG-3; BMS-986016) in combination with nivolumab (nivo) in pts with melanoma (MEL) previously treated with anti-PD-1/ PD-L1 therapy. J Clin Oncol. 2017;35(15 suppl):9520.

105 Monney L, Sabatos CA, Gaglia JL, Ryu A, Waldner $\mathrm{H}$, Chernova T, et al. Th1-specific cell surface protein Tim- 3 regulates macrophage activation and severity of an autoimmune disease. Nature. 2002 Jan;415(6871): 536-41.

$106 \mathrm{Li}$ Z, Ju Z, Frieri M. The T-cell immunoglobulin and mucin domain (Tim) gene family in asthma, allergy, and autoimmunity. Allergy Asthma Proc. 2013 Jan-Feb;34(1):e21-6.

107 He Y, Cao J, Zhao C, Li X, Zhou C, Hirsch FR. TIM-3, a promising target for cancer immunotherapy. OncoTargets Ther. 2018 Oct; 11:7005-9.

108 Meyers JH, Sabatos CA, Chakravarti S, Kuchroo VK. The TIM gene family regulates autoimmune and allergic diseases. Trends Mol Med. 2005 Aug;11(8):362-9.

109 Zhu C, Anderson AC, Schubart A, Xiong H, Imitola J, Khoury SJ, et al. The Tim-3 ligand galectin-9 negatively regulates $\mathrm{T}$ helper type 1 immunity. Nat Immunol. 2005 Dec;6(12): 1245-52.

110 Liu Y, Shu Q, Gao L, Hou N, Zhao D, Liu X, et al. Increased Tim-3 expression on peripheral lymphocytes from patients with rheumatoid arthritis negatively correlates with disease activity. Clin Immunol. 2010 Nov; 137(2):288-95.

111 Morimoto K, Hosomi S, Yamagami H, Watanabe K, Kamata N, Sogawa M, et al. Dysregulated upregulation of T-cell immunoglobulin and mucin domain-3 on mucosal T helper 1 cells in patients with Crohn's disease. Scand J Gastroenterol. 2011 Jun; 46(6):701-9.

112 Kanzaki M, Wada J, Sugiyama K, Nakatsuka A, Teshigawara S, Murakami K, et al. Galectin-9 and $\mathrm{T}$ cell immunoglobulin mucin-3 pathway is a therapeutic target for type 1 diabetes. Endocrinology. 2012 Feb;153(2):61220.

113 Li S, Peng D, He Y, Zhang H, Sun H, Shan S, et al. Expression of TIM-3 on CD4+ and $\mathrm{CD} 8+\mathrm{T}$ cells in the peripheral blood and synovial fluid of rheumatoid arthritis. APMIS. 2014 Oct;122(10):899-904.

114 Das M, Zhu C, Kuchroo VK. Tim-3 and its role in regulating anti-tumor immunity. Immunol Rev. 2017 Mar;276(1):97-111.

115 Fourcade J, Sun Z, Benallaoua M, Guillaume P, Luescher IF, Sander C, et al. Upregulation of Tim-3 and PD-1 expression is associated with tumor antigen-specific CD8+ T cell dysfunction in melanoma patients. J Exp Med. 2010 Sep;207(10):2175-86.
116 Sakuishi K, Apetoh L, Sullivan JM, Blazar BR, Kuchroo VK, Anderson AC. Targeting Tim-3 and PD-1 pathways to reverse T cell exhaustion and restore anti-tumor immunity. J Exp Med. 2010 Sep;207(10):2187-94.

117 Yang ZZ, Grote DM, Ziesmer SC, Niki T, Hirashima M, Novak AJ, et al. IL-12 upregulates TIM-3 expression and induces T cell exhaustion in patients with follicular B cell non-Hodgkin lymphoma. J Clin Invest. 2012 Apr;122(4):1271-82.

118 Guo Z, Cheng D, Xia Z, Luan M, Wu L, Wang $\mathrm{G}$, et al. Combined TIM-3 blockade and CD137 activation affords the long-term protection in a murine model of ovarian cancer. J Transl Med. 2013 Sep;11(1):215.

119 Zhu C, Sakuishi K, Xiao S, Sun Z, Zaghouani $\mathrm{S}, \mathrm{Gu} \mathrm{G}$, et al. An IL-27/NFIL3 signalling axis drives Tim-3 and IL-10 expression and T-cell dysfunction. Nat Commun. 2015 Jan; 6(1):6072.

$120 \mathrm{Lu}$ X, Yang L, Yao D, Wu X, Li J, Liu X, et al. Tumor antigen-specific CD8+ $\mathrm{T}$ cells are negatively regulated by PD-1 and Tim-3 in human gastric cancer. Cell Immunol. 2017 Mar;313:43-51

121 Piao Y, Jin X:Analysis of TIM-3 as a therapeutic target in prostate cancer. Tumour Biol. 2017;39:1010428317716628.

122 Lee J, Su EW, Zhu C, Hainline S, Phuah J, Moroco JA, et al. Phosphotyrosine-dependent coupling of Tim-3 to T-cell receptor signaling pathways. Mol Cell Biol. 2011 Oct; 31(19):3963-74.

123 Kang CW, Dutta A, Chang LY, Mahalingam J, Lin YC, Chiang JM, et al. Apoptosis of tumor infiltrating effector TIM-3+CD8+ T cells in colon cancer. Sci Rep. 2015 Oct;5(1): 15659.

124 Nakae S, Iikura M, Suto H, Akiba H, Umetsu DT, Dekruyff RH, et al. TIM-1 and TIM-3 enhancement of Th2 cytokine production by mast cells. Blood. 2007 Oct;110(7):2565-

125 Gleason MK, Lenvik TR, McCullar V, Felices M, O’Brien MS, Cooley SA, et al. Tim-3 is an inducible human natural killer cell receptor that enhances interferon gamma production in response to galectin-9. Blood. 2012 Mar;119(13):3064-72.

126 Nakayama M, Akiba H, Takeda K, Kojima Y, Hashiguchi M, Azuma M, et al. Tim-3 mediates phagocytosis of apoptotic cells and cross-presentation. Blood. 2009 Apr; 113 (16):3821-30.

127 DeKruyff RH, Bu X, Ballesteros A, Santiago C, Chim YL, Lee HH, et al. T cell/transmembrane, Ig, and mucin-3 allelic variants differentially recognize phosphatidylserine and mediate phagocytosis of apoptotic cells. J Immunol. 2010 Feb;184(4):1918-30.

128 Steinman RM, Banchereau J. Taking dendritic cells into medicine. Nature. 2007;449: $419-26$. 
129 Chiba S, Baghdadi M, Akiba H, Yoshiyama $\mathrm{H}$, Kinoshita I, Dosaka-Akita H, et al. Tumor-infiltrating DCs suppress nucleic acidmediated innate immune responses through interactions between the receptor TIM-3 and the alarmin HMGB1. Nat Immunol. 2012 Sep;13(9):832-42.

130 Patel J, Bozeman EN, Selvaraj P. Taming dendritic cells with TIM-3: another immunosuppressive strategy used by tumors. Immunotherapy. 2012 Dec;4(12):1795-8.

131 Huang YH, Zhu C, Kondo Y, Anderson AC, Gandhi A, Russell A, et al. CEACAM1 regulates TIM-3-mediated tolerance and exhaustion. Nature. 2015 Jan;517(7534):386-90.

132 Banerjee H, Kane LP. Immune regulation by TIM-3. F1000 Res. 2018 Mar;7:316.

133 Du W, Yang M, Turner A, Xu C, Ferris RL, Huang J, et al. TIM-3 as a Target for Cancer Immunotherapy and Mechanisms of Action. Int J Mol Sci. 2017 Mar;18(3):E645.

134 van de Weyer PS, Muehlfeit M, Klose C, Bonventre JV, Walz G, Kuehn EW. A highly conserved tyrosine of Tim-3 is phosphorylated upon stimulation by its ligand galectin-9. Biochem Biophys Res Commun. 2006 Dec;351(2):571-6.

135 Rangachari M, Zhu C, Sakuishi K, Xiao S, Karman J, Chen A, et al. Bat3 promotes T cell responses and autoimmunity by repressing Tim-3-mediated cell death and exhaustion. Nat Med. 2012 Sep;18(9):1394-400.

136 Jan M, Chao MP, Cha AC, Alizadeh AA, Gentles AJ, Weissman IL, et al. Prospective separation of normal and leukemic stem cells based on differential expression of TIM3, a human acute myeloid leukemia stem cell marker. Proc Natl Acad Sci USA. 2011 Mar;108(12):5009-14.

137 Jie HB, Gildener-Leapman N, Li J, Srivastava RM, Gibson SP, Whiteside TL, et al. Intratumoral regulatory $\mathrm{T}$ cells upregulate immunosuppressive molecules in head and neck cancer patients. Br J Cancer. 2013 Nov; 109(10):2629-35.

138 Yan J, Zhang Y, Zhang JP, Liang J, Li L, Zheng L. Tim-3 expression defines regulatory $\mathrm{T}$ cells in human tumors. PLoS One. 2013;8(3):e58006.

139 Japp AS, Kursunel MA, Meier S, Mälzer JN, Li X, Rahman NA, et al. Dysfunction of PSAspecific CD8+ T cells in prostate cancer patients correlates with CD38 and Tim-3 expression. Cancer Immunol Immunother. 2015 Nov;64(11):1487-94.

140 Thommen DS, Schreiner J, Müller P, Herzig P, Roller A, Belousov A, et al. Progression of lung cancer is associated with increased dysfunction of $\mathrm{T}$ cells defined by coexpression of multiple inhibitory receptors. Cancer Immunol Res. 2015 Dec;3(12):1344-55.

141 Cheng G, Li M, Wu J, Ji M, Fang C, Shi H, et al. Expression of Tim-3 in gastric cancer tissue and its relationship with prognosis. Int J Clin Exp Pathol. 2015 Aug;8(8):9452-7.
142 Cai C, Xu YF, Wu ZJ, Dong Q, Li MY, Olson JC, et al. Tim-3 expression represents dysfunctional tumor infiltrating $\mathrm{T}$ cells in renal cell carcinoma. World J Urol. 2016 Apr; 34(4):561-7.

143 Xie J, Wang J, Cheng S, Zheng L, Ji F, Yang $\mathrm{L}$, et al. Expression of immune checkpoints in T cells of esophageal cancer patients. Oncotarget. 2016 Sep;7(39):63669-78.

144 Baitsch L, Baumgaertner P, Devêvre E, Raghav SK, Legat A, Barba L, et al. Exhaustion of tumor-specific $\mathrm{CD} 8^{+} \mathrm{T}$ cells in metastases from melanoma patients. J Clin Invest. 2011 Jun;121(6):2350-60.

145 Gao X, Zhu Y, Li G, Huang H. Zhang, Wang F, Sun J, Yang Q, Zhang X, Lu B: TIM-3 expression characterizes regulatory $\mathrm{T}$ cells in tumour tissues and is associated with lung cancer progression. PLoS One. 2012;7(2): e30676.

146 Sakuishi K, Ngiow SF, Sullivan JM, Teng MW, Kuchroo VK, Smyth MJ, et al. TIM3+FOXP3+ regulatory $\mathrm{T}$ cells are tissue-specific promoters of T-cell dysfunction in cancer. OncoImmunology. 2013 Apr; 2(4):e23849.

147 Wiener Z, Kohalmi B, Pocza P, Jeager J, Tolgyesi G, Toth S, et al. TIM-3 is expressed in melanoma cells and is upregulated in TGFbeta stimulated mast cells. J Invest Dermatol. 2007 Apr;127(4):906-14.

148 Kikushige Y, Shima T, Takayanagi S, Urata $\mathrm{S}$, Miyamoto T, Iwasaki $\mathrm{H}$, et al. TIM-3 is a promising target to selectively kill acute myeloid leukemia stem cells. Cell Stem Cell. 2010 Dec;7(6):708-17.

149 Huang X, Bai X, Cao Y, Wu J, Huang M, Tang D, et al. Lymphoma endothelium preferentially expresses Tim- 3 and facilitates the progression of lymphoma by mediating immune evasion. J Exp Med. 2010 Mar;207(3): 505-20.

150 Cao Y, Zhou X, Huang X, Li Q, Gao L, Jiang L, et al. TIM-3 expression in cervical cancer promotes tumor metastasis. PLoS One. 2013;8(1):e53834.

151 Shang Y, Li Z, Li H, Xia H, Lin Z. TIM-3 expression in human osteosarcoma: correlation with the expression of epithelial-mesenchymal transition-specific biomarkers. Oncol Lett. 2013 Aug;6(2):490-4.

152 Komohara Y, Morita T, Annan DA, Horlad $\mathrm{H}$, Ohnishi K, Yamada S, et al. The coordinated actions of TIM-3 on cancer and myeloid cells in the regulation of tumorigenicity and clinical prognosis in clear cell renal cell carcinomas. Cancer Immunol Res. 2015 Sep;3(9):999-1007.

153 Gonçalves Silva I, Gibbs BF, Bardelli M, Varani L, Sumbayev VV. Differential expression and biochemical activity of the immune receptor Tim-3 in healthy and malignant human myeloid cells. Oncotarget. 2015 Oct; 6(32):33823-33.
154 Koyama S, Akbay EA, Li YY, Herter-Sprie GS, Buczkowski KA, Richards WG, et al. Adaptive resistance to therapeutic PD-1 blockade is associated with upregulation of alternative immune checkpoints. Nat Commun. 2016 Feb;7(1):10501.

$155 \mathrm{Yu}$ X, Harden K, Gonzalez LC, Francesco M, Chiang E, Irving B, et al. The surface protein TIGIT suppresses $\mathrm{T}$ cell activation by promoting the generation of mature immunoregulatory dendritic cells. Nat Immunol. 2009 Jan;10(1):48-57.

156 Johnston RJ, Comps-Agrar L, Hackney J, Yu $\mathrm{X}$, Huseni M, Yang Y, et al. The immunoreceptor TIGIT regulates antitumor and antiviral CD8(+) T cell effector function. Cancer Cell. 2014 Dec;26(6):923-37.

157 Solomon BL, Garrido-Laguna I. TIGIT: a novel immunotherapy target moving from bench to bedside. Cancer Immunol Immunother. 2018 Nov;67(11):1659-67.

158 Boles KS, Vermi W, Facchetti F, Fuchs A Wilson TJ, Diacovo TG, Cella M, Colonna M: A novel molecular interaction for the adhesion of follicular CD4 T cells to follicular DC. Eur J Immunol. 2009;39(3):695-703.

159 Levin SD, Taft DW, Brandt CS, Bucher C, Howard ED, Chadwick EM, et al. Vstm3 is a member of the CD28 family and an important modulator of T-cell function. Eur J Immunol. 2011 Apr;41(4):902-15.

160 Lozano E, Dominguez-Villar M, Kuchroo V, Hafler DA. The TIGIT/CD226 axis regulates human T cell function. J Immunol. 2012 Apr;188(8):3869-75.

161 Joller N, Lozano E, Burkett PR, Patel B, Xiao $\mathrm{S}$, Zhu C, et al. Treg cells expressing the coinhibitory molecule TIGIT selectively inhibit proinflammatory Th1 and Th17 cell responses. Immunity. 2014 Apr;40(4):569-81.

162 Manieri NA, Chiang EY, Grogan JL. TIGIT: A Key Inhibitor of the Cancer Immunity Cycle. Trends Immunol. 2017 Jan;38(1):20-8.

163 Stengel KF, Harden-Bowles K, Yu X, Rouge L, Yin J, Comps-Agrar L, et al. Structure of TIGIT immunoreceptor bound to poliovirus receptor reveals a cell-cell adhesion and signaling mechanism that requires cis-trans receptor clustering. Proc Natl Acad Sci USA. 2012 Apr;109(14):5399-404.

164 Casado JG, Pawelec G, Morgado S, SanchezCorrea B, Delgado E, Gayoso I, et al. Expression of adhesion molecules and ligands for activating and costimulatory receptors involved in cell-mediated cytotoxicity in a large panel of human melanoma cell lines. Cancer Immunol Immunother. 2009 Sep 58(9):1517-26.

165 Stanietsky N, Rovis TL, Glasner A, Seidel E, Tsukerman P, Yamin R, et al. Mouse TIGIT inhibits NK-cell cytotoxicity upon interaction with PVR. Eur J Immunol. 2013 Aug; 43(8):2138-50.

166 Anderson AC, Joller N, Kuchroo VK. Lag-3, Tim-3, and TIGIT: Co-inhibitory Receptors with Specialized Functions in Immune Regulation. Immunity. 2016 May;44(5):989-1004. 
167 Stanietsky N, Simic H, Arapovic J, Toporik A, Levy O, Novik A, et al. The interaction of TIGIT with PVR and PVRL2 inhibits human NK cell cytotoxicity. Proc Natl Acad Sci USA. 2009 Oct;106(42):17858-63.

168 Liu S, Zhang H, Li M, Hu D, Li C, Ge B, et al. Recruitment of Grb2 and SHIP1 by the ITTlike motif of TIGIT suppresses granule polarization and cytotoxicity of NK cells. Cell Death Differ. 2013 Mar;20(3):456-64.

169 Li M, Xia P, Du Y, Liu S, Huang G, Chen J, et al. T-cell immunoglobulin and ITIM domain (TIGIT) receptor/poliovirus receptor (PVR) ligand engagement suppresses interferon- $\gamma$ production of natural killer cells via $\beta$-arrestin 2-mediated negative signaling. J Biol Chem. 2014 Jun;289(25): 17647-57.

170 Fuhrman CA, Yeh WI, Seay HR, Saikumar Lakshmi P, Chopra G, Zhang L, et al. Divergent phenotypes of human regulatory $\mathrm{T}$ cells expressing the receptors TIGIT and CD226. J Immunol. 2015 Jul;195(1):145-55.

171 Kurtulus S, Sakuishi K, Ngiow SF, Joller N, Tan DJ, Teng MW, et al. TIGIT predominantly regulates the immune response via regulatory T cells. J Clin Invest. 2015 Nov; 125(11):4053-62.

172 Chan LL, Cheung BK, Li JC, Lau AS. A role for STAT3 and cathepsin S in IL-10 downregulation of IFN-gamma-induced MHC class II molecule on primary human blood macrophages. J Leukoc Biol. 2010 Aug; 88(2):303-11.
173 Chauvin JM, Pagliano O, Fourcade J, Sun Z, Wang H, Sander C, et al. TIGIT and PD-1 impair tumor antigen-specific $\mathrm{CD}^{+} \mathrm{T}$ cells in melanoma patients. J Clin Invest. 2015 May;125(5):2046-58.

174 Lee WJ, Lee YJ, Choi ME, Yun KA, Won $\mathrm{CH}$ Lee MW, et al. LAG-3 and TIGIT protein expressions in cutaneous melanoma and their relationship with PD-1 tumour-infiltrating lymphocytes. J Am Acad Dermatol. 2019;9622:30426-8.

175 Kong Y, Zhu L, Schell TD, Zhang J, Claxton DF, Ehmann WC, et al. T-Cell Immunoglobulin and ITIM Domain (TIGIT) Associates with CD8+ T-Cell Exhaustion and Poor Clinical Outcome in AML Patients. Clin Cancer Res. 2016 Jun;22(12):3057-66.

176 He R, Hou S, Liu C, Zhang A, Bai Q, Han M, et al. Follicular CXCR5-expressing CD8(+) $\mathrm{T}$ cells curtail chronic viral infection. Nature. 2016 Aug;537(7620):412-28.

177 Im SJ, Hashimoto M, Gerner MY, Lee J, Kissick HT, Burger MC, et al. Defining CD8+ T cells that provide the proliferative burst after PD-1 therapy. Nature. 2016 Sep;537(7620): 417-21.

178 Zhao Y, Yang W, Huang Y, Cui R, Li X, Li B. Evolving Roles for Targeting CTLA-4 in Cancer Immunotherapy. Cell Physiol Biochem. 2018;47(2):721-34.
179 Mitsuiki N, Schwab C, Grimbacher B. What did we learn from CTLA-4 insufficiency on the human immune system? Immunol Rev. 2019 Jan;287(1):33-49.

180 Esensten JH, Helou YA, Chopra G, Weiss A, Bluestone JA. CD28 costimulation: from mechanism to therapy. Immunity. 2016 May;44(5):973-88.

181 Wolchok JD, Saenger Y. The mechanism of anti-CTLA-4 activity and the negative regulation of T-cell activation. Oncologist. 2008; 13 Suppl 4:2-9.

182 Buchbinder EI, Desai A. CTLA-4 and PD-1 pathways: similarities, differences, and implications of their Inhibition. Am J Clin Oncol. 2016 Feb;39(1):98-106.

183 Boussiotis VA. Molecular and Biochemical Aspects of the PD-1 Checkpoint Pathway. N Engl J Med. 2016 Nov;375(18):1767-78.

184 Freeman GJ, Long AJ, Iwai Y, Bourque K, Chernova T, Nishimura H, et al. Engagement of the PD-1 immunoinhibitory receptor by a novel B7 family member leads to negative regulation of lymphocyte activation. J Exp Med. 2000 Oct;192(7):1027-34.

185 Robainas M, Otano R, Bueno S, Ait-Oudhia $\mathrm{S}$. Understanding the role of PD-L1/PD1 pathway blockade and autophagy in cancer therapy. OncoTargets Ther. 2017 Mar; 10: 1803-7.

186 Ribas A, Wolchok JD. Cancer immunotherapy using checkpoint blockade. Science. 2018 Mar;359(6382):1350-5. 